\title{
Preliminary GIS Representation of Deep Coal Areas for Carbon Dioxide Storage in the Contiguous United States and Alaska
}

Open-File Report 2018-1178 



\section{Preliminary GIS Representation of Deep Coal Areas for Carbon Dioxide Storage in the Contiguous United States and Alaska}

By Kevin B. Jones, Laura E. Barnhart, Peter D. Warwick, and Margo D. Corum

Open-File Report 2018-1178 


\title{
U.S. Department of the Interior \\ DAVID BERNHARDT, Acting Secretary \\ U.S. Geological Survey \\ JAMES F. REILLY II, Director
}

\author{
U.S. Geological Survey, Reston, Virginia: 2019
}

For more information on the USGS - the Federal source for science about the Earth, its natural and living resources, natural hazards, and the environment-visit https://www.usgs.gov or call 1-888-ASK-USGS.

For an overview of USGS information products, including maps, imagery, and publications,

visit https://store.usgs.gov.

Any use of trade, firm, or product names is for descriptive purposes only and does not imply endorsement by the U.S. Government.

Although this information product, for the most part, is in the public domain, it also may contain copyrighted materials as noted in the text. Permission to reproduce copyrighted items must be secured from the copyright owner.

Suggested citation:

Jones, K.B., Barnhart, L.E., Warwick, P.D., and Corum, M.D., 2019, Preliminary GIS representation of deep coal areas for carbon dioxide storage in the contiguous United States and Alaska: U.S. Geological Survey Open-File Report 2018-1178, 21 p., https://doi.org/10.3133/ofr20181178.

ISSN 2331-1258 (online) 


\section{Contents}

Abstract

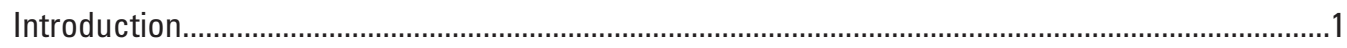

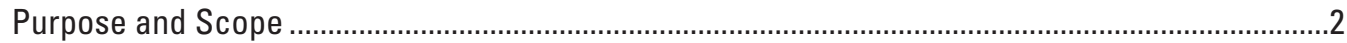

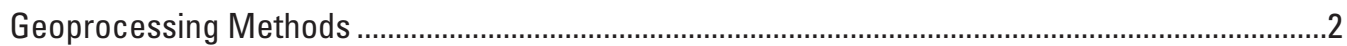

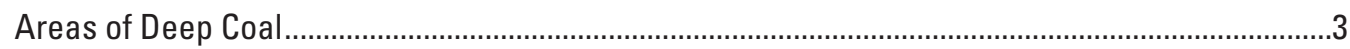

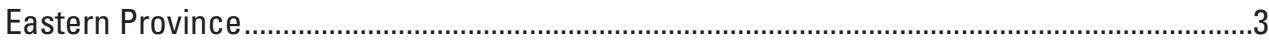

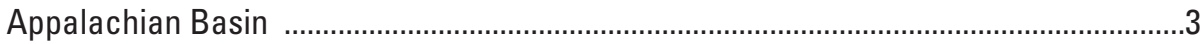

Black Warrior Basin and Southern Appalachian Thrust Belt ............................................3

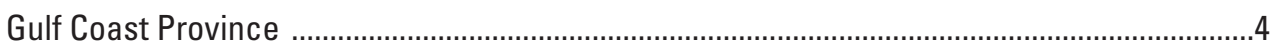

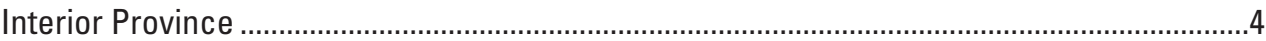

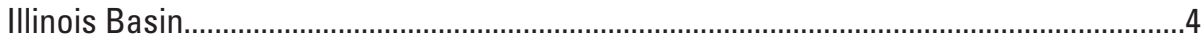

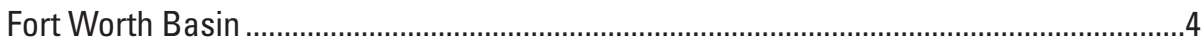

Western Interior Coal Region ........................................................................................

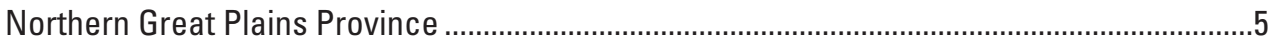

Powder River Basin ..................................................................................................

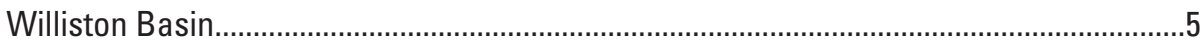

Rocky Mountain Province .....................................................................................................

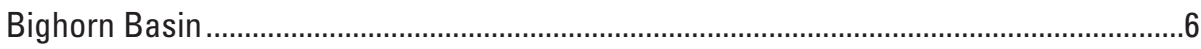

Wind River Basin ......................................................................................................

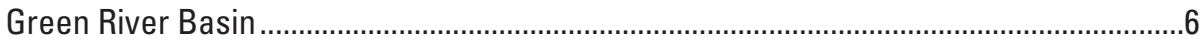

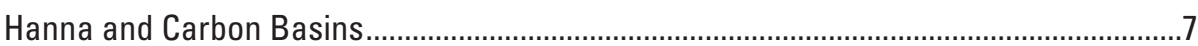

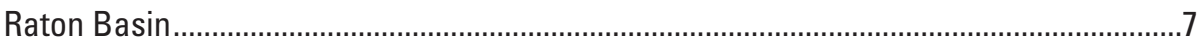

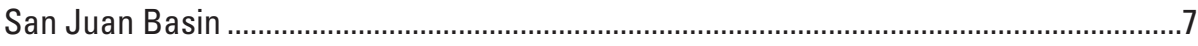

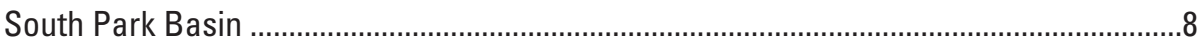

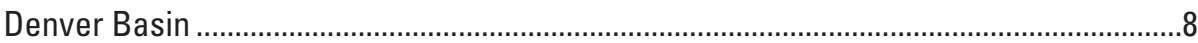

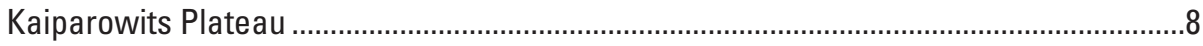

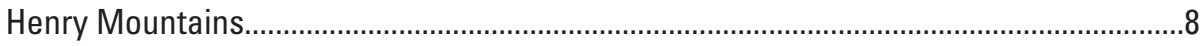

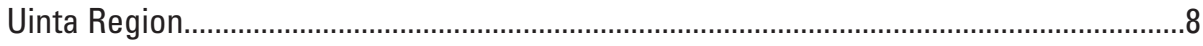

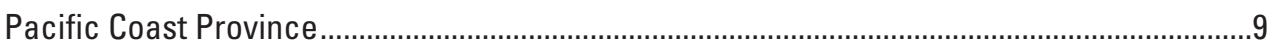

Bellingham Basin and Glacier Coal Field .......................................................................

Wilkeson-Carbonado Coal Field ..............................................................................

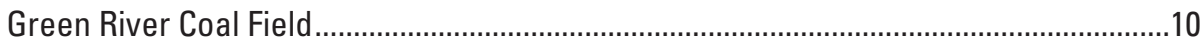

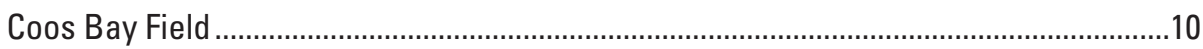

North Slope (Alaska) Province ..........................................................................................10

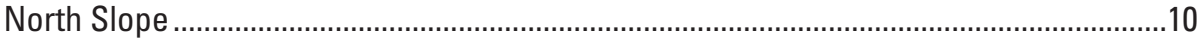

Southern Alaska-Cook Inlet Province ………....................................................................

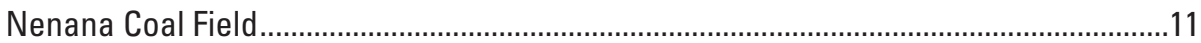

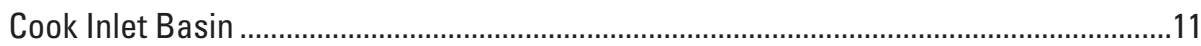

Areas with Insufficient Deep Coal for Carbon Dioxide Storage ....................................................11

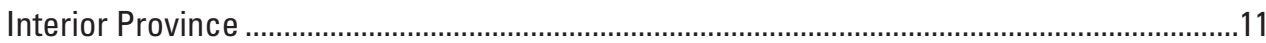

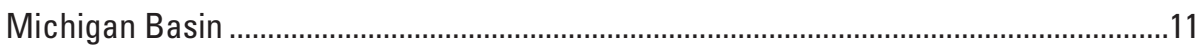

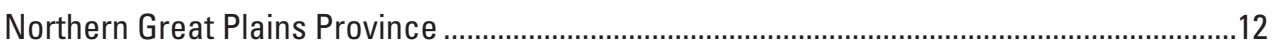

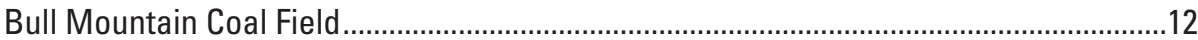


North-Central Region ................................................................................................

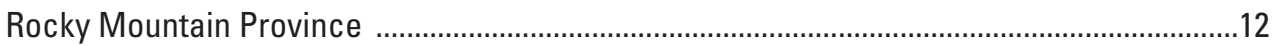

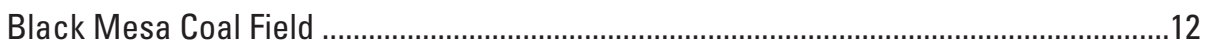

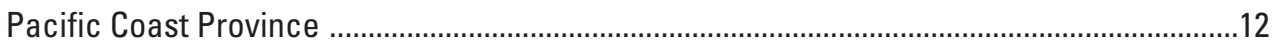

Centralia and Roslyn Coal Fields ....................................................................................

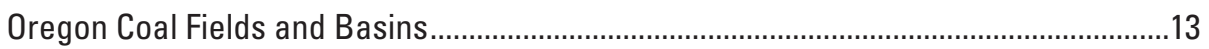

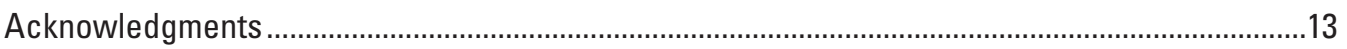

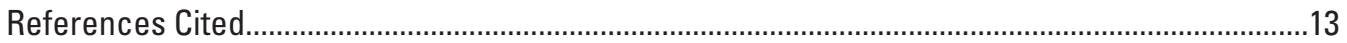

\section{Conversion Factors}

U.S. customary units to International System of Units

\begin{tabular}{|c|c|c|}
\hline Multiply & By & To obtain \\
\hline \multicolumn{3}{|c|}{ Length } \\
\hline inch (in.) & 2.54 & centimeter $(\mathrm{cm})$ \\
\hline inch (in.) & 25.4 & millimeter $(\mathrm{mm})$ \\
\hline foot $(\mathrm{ft})$ & 0.3048 & meter $(\mathrm{m})$ \\
\hline mile (mi) & 1.609 & kilometer (km) \\
\hline yard (yd) & 0.9144 & meter $(\mathrm{m})$ \\
\hline \multicolumn{3}{|c|}{ Mass } \\
\hline ton, short $(2,000 \mathrm{lb})$ & 0.9072 & metric ton $(\mathrm{t})$ \\
\hline ton, long $(2,240 \mathrm{lb})$ & 1.016 & metric ton $(\mathrm{t})$ \\
\hline
\end{tabular}

\section{Abbreviations}

CBM coalbed methane

DOE U.S. Department of Energy

ECBM enhanced coalbed methane recovery

EPA U.S. Environmental Protection Agency

NCRA National Coal Resource Assessment

NCRDS National Coal Resources Data System

NETL National Energy Technology Laboratory

USGS U.S. Geological Survey 



\title{
Preliminary GIS Representation of Deep Coal Areas for Carbon Dioxide Storage in the Contiguous United States and Alaska
}

\author{
By Kevin B. Jones, Laura E. Barnhart, Peter D. Warwick, and Margo D. Corum
}

\begin{abstract}
This report and its accompanying geospatial data outline many areas of coal in the United States beneath more than 3,000 ft of overburden. Based on depth, these areas may be targets for injection and storage of supercritical carbon dioxide. Additional areas where coal exists beneath more than $1,000 \mathrm{ft}$ of overburden are also outlined; these may be targets for geologic storage of carbon dioxide in conjunction with enhanced coalbed methane production. These areas of deep coal were compiled as polygons into a shapefile for use in a geographic information system (GIS). The coal-bearing formation names, coal basin or field names, geographic provinces, coal ranks, coal geologic ages, and estimated individual coalbed thicknesses (if known) of the coal-bearing formations were included. An additional point shapefile, coal_co2_projects.shp, contains the locations of pilot projects for carbon dioxide injection into coalbeds. This report is not a comprehensive study of deep coal in the United States. Some areas of deep coal were excluded based on geologic or data-quality criteria, while others may be absent from the literature and still others may have been overlooked by the authors.
\end{abstract}

\section{Introduction}

Storing carbon dioxide $\left(\mathrm{CO}_{2}\right)$ geologically prevents its release into the atmosphere and contribution to global climate change as a greenhouse gas. The Energy Independence and Security Act of 2007 (Public Law 110-140) directed the U.S. Geological Survey (USGS) to assess potential resources for geologic storage of carbon dioxide in the United States. This assessment was to include conventional reservoirs for storing carbon dioxide — sandstones, limestones, and dolostones, overlain by a low-permeability sealing layer - and other, unconventional storage lithologies, including "unminable" coalbeds deep enough to make coal recovery uneconomical. The assessment of conventional resources for geologic storage of carbon dioxide was completed in 2013 (U.S. Geological Survey Geologic Carbon Dioxide Storage Resources Assessment Team, 2013).

Carbon dioxide injected into deep coalbeds can be trapped in the coal pore structure or adsorbed to the coal by molecular bonds, thereby storing the injected carbon dioxide (Wickstrom and others, 2005). In preparation for probabilistic assessments of potential resources for carbon dioxide storage in coalbeds, the USGS Geologic Carbon Sequestration Project assembled a team of experts from academia, industry, and government to recommend parameters and procedures that could enable assessment of the geologic storage potential of unconventional reservoirs, including coal (Jones and Blondes, 2015). The team recommended that candidate coalbeds must be at least $3,000 \mathrm{ft}$ deep for consideration as carbon dioxide storage to ensure that the injected carbon dioxide remains a supercritical fluid due to lithostatic pressure, maximizing the amount of carbon dioxide stored per unit volume of the reservoir. However, coals deeper than $3,000 \mathrm{ft}$ with enough porosity and permeability to allow carbon dioxide injection may be hard to find in many basins, and most validation or pilot projects for carbon dioxide storage in coal to date (2016) have injected carbon dioxide in a non-supercritical state at 1,000-3,000 ft deep. These projects are also associated with enhanced coalbed methane (ECBM) production: the injected carbon dioxide strongly adsorbs to organics in the pore structure of the coal, displacing and releasing methane, which can then potentially be captured for economic benefit.

The team also recommended dropping the term "unminable" from the description of coalbeds potentially used to store carbon dioxide, because coalbeds deeper than 3,000 ft could technically be mined, although not economically at present. Additionally, groundwater in coalbeds possibly considered for carbon dioxide storage should contain more than $10,000 \mathrm{mg} / \mathrm{L}$ total dissolved solids as mandated by U.S. Environmental Protection Agency (EPA) standards for underground storage of carbon dioxide and the protection of potential underground sources of drinking water (EPA, 2009, 2010; 40 CFR 146.3). The team also recommended that a low-permeability sealing formation above coalbeds be required for coals to be considered for carbon dioxide storage and that coalbeds of all thicknesses be considered for carbon dioxide storage.

Any data files discussed in this report that are not characterized as belonging to a cited source can be found in the U.S. Geological Survey data release (Jones and others, 2019) associated with this report. 


\section{Purpose and Scope}

This report and its accompanying geospatial data outline many areas of coal in the major coal basins of the United States beneath more than 3,000 ft of overburden. Based on depth, these areas may be targets for injection and storage of supercritical carbon dioxide. Additional areas where coal exists beneath more than 1,000 ft of overburden are also outlined; these may be targets for geologic storage of carbon dioxide only in conjunction with enhanced coalbed methane production. The areas where coal exists beneath at least 3,000 ft of overburden, and additional areas where coal exists beneath at least 1,000 ft of overburden, were compiled as polygons into a shapefile (deep_coal_us.shp) for use in a geographic information system (GIS). The coalbearing formation names, coal basin or field names, geographic provinces, coal ranks, coal geologic ages, and estimated individual coalbed thicknesses (if known) of the coal-bearing formations were included as attributes (FORMATION, NAME, PROVINCE, RANK, AGE, and THICKNESS). The depth-to-coal category (either $>3,000$ or 1,000-3,000, in units of ft) was also included as the attribute DEPTH_FT.

An additional point shapefile, coal_co2_projects.shp, contains the locations of pilot projects for carbon dioxide injection into coalbeds. Data about the projects - the project name, managing organization, coal basin, target coal-bearing formation, depth of injection, year injection began, mass of carbon dioxide stored geologically, county, and State - are included as attributes Proj_name, management, coal_basin, coal_field, depths, inject_yr, mass_stord, county, and State, respectively.

This report is not a comprehensive study of deep coal in the United States. Some areas of deep coal were excluded based on geologic or data-quality criteria, while others may be absent from the literature and still others may have been overlooked by the authors. Most coal research and geospatial data focus on shallow, economically recoverable coal. If the literature does not contain information regarding deep coal in a particular basin, it can be hard to tell whether deep coal is absent from the basin or there was no previous interest in, or research on, the basin's deep coal. Coal-depth information can be limited by the maximum depths of wells. Although drilling for coalbed methane often ends upon reaching a coalbed of economic value, wells drilled for other reasons - such as for producing oil or gas - may stop before intersecting deep coalbeds, resulting in no data on these coals.

\section{Geoprocessing Methods}

The geoprocessing steps used to create the polygons representing deep coal varied between coal basins because the source data - mainly preexisting GIS layers, overburden maps, geologic structure maps, digital elevation models (DEMs), and well-log information_varies between basins. The accompanying deep_coal_us.shp shapefile contains polygons created by one or more of the generic geoprocessing steps in the following list, using QGIS or ESRI ArcGIS software.

1. Select and export USGS National Coal Resource Assessment (NCRA) polygons corresponding to overburden categories greater than 3,000 ft or 1,000 ft. The NCRA is a series of regional-scale reports and GIS data. The NCRA assessed many, but not all, domestic coal basins; additional sources of information are needed, especially for areas outside the scope of the NCRA (Pierce and Dennen, 2009).

1. Scan and georeference coal overburden maps that are of an appropriate scale for this project, digitize $3,000 \mathrm{ft}$ and $1,000 \mathrm{ft}$ overburden contours, and use these contours and the outlines of coal basins from East (2013) to create polygons representing coal deeper than $3,000 \mathrm{ft}$ and $1,000 \mathrm{ft}$.

2. Calculate coal overburden using the following steps: (a) Create structure contours of the coal from existing coal structure maps; (b) convert these contours into a raster DEM; (c) subtract the coal structure DEM from a ground surface DEM to create a model of the overburden; (d) create 3,000 ft and 1,000 ft contours from the coal overburden model; (e) and use these contours and the outlines of coal basins to create polygons representing coal deeper than $3,000 \mathrm{ft}$ and $1,000 \mathrm{ft}$.

3. Interpolate depth-to-coal points from well data using inverse-distance weighting to produce raster data of coal overburden, then create $3,000 \mathrm{ft}$ and $1,000 \mathrm{ft}$ contours from these raster data and use these contours and the outlines of coal basins to create polygons representing coal deeper than 3,000 ft and 1,000 ft. Main sources of well data were the Petroleum Information Data Model (PIDM) database (IHS Inc., 2010) and the USGS National Coal Resources Data System (NCRDS; U.S. Geological Survey, 2012). The NCRDS consists of the USTRAT database of stratigraphic information, including well data, the USCHEM database of coal chemistry, and the USCOAL database of historic coal resource assessments. References to NCRDS in this document refer specifically to the USTRAT component.

More detailed descriptions of the geoprocessing steps used in each coal basin, if needed, are below in the Areas of Deep Coal section. Completed and ongoing pilot projects for coalbed carbon dioxide injection are represented as points in the accompanying coal_co2_projects.shp shapefile and are described below in the Areas of Deep Coal section. 


\section{Areas of Deep Coal}

\section{Eastern Province}

\section{Appalachian Basin}

The Appalachian Basin contains bituminous coal in the Lower to Middle Pennsylvanian Pottsville Group, Middle Pennsylvanian Allegheny Group, and Upper Pennsylvanian Conemaugh and Monongahela Groups. Appalachian Basin cross sections of Ryder and others (C-C', 2012; D-D', 2009; E-E', 2008; and I-I', 2015) show parts of the coal-bearing Pottsville, Allegheny, and Conemaugh Groups deeper than 1,000 ft. Only small areas of coal deeper than 3,000 ft are shown; these are in the Pottsville Group on cross section I-I'. These areas of deep coal generally match the locations of areas with more than 1,000 and 3,000 ft of overburden in the geospatial data of the Northern and Central Appalachian Basin Coal Regions Assessment Team (2001).

Shapefiles representing the overburden thicknesses of the Allegheny Group's Upper Freeport coalbed; the Monongahela Group's Pittsburgh coalbed; and the Pottsville Group's Pocahontas coalbed, Pond Creek coal zone, and Fireclay coal zonec9011ob.shp, c9024ob.shp, c9104ob.shp, c9120ob.shp, and c9125ob.shp, respectively-were obtained from U.S. Geological Survey Professional Paper 1625-C (Northern and Central Appalachian Basin Coal Regions Assessment Team, 2001). Polygons with ob_cat attributes of 109, corresponding to overburden thicknesses of 3,000-6,000 ft, were merged to create the polygons for coal at greater than $3,000 \mathrm{ft}$ depth. Polygons with ob_cat attributes of 107 or 108, corresponding to overburden thicknesses of 1,000-2,000 ft and 2,000-3,000 ft, respectively, were merged to create the polygons for coal at depths of 1,000-3,000 ft in the northern and central Appalachian Basin. (The southern Appalachian Basin is addressed in the following section, "Black Warrior Basin and Southern Appalachian Thrust Belt.”)

In January 2009, the Southeastern Regional Carbon Sequestration Partnership (SECARB) injected about 900 metric tons of carbon dioxide into the coal seams of the Pottsville Group's Pocahontas and Lee Formations in Russell County, Virginia, in the central Appalachian Basin. This project included recovery of coalbed methane produced as a result of the carbon dioxide injection. Injection depth was between 1,400 and 2,200 ft (National Energy Technology Laboratory, 2012; Gilliland and others, 2013).

\section{Black Warrior Basin and Southern Appalachian Thrust Belt}

Coals in the Black Warrior Basin and the adjacent southern Appalachian thrust belt are divided between the Warrior, Coosa, and Cahaba coal basins and are all stratigraphically in the Lower to Middle Pennsylvanian Pottsville Formation. The Warrior coal basin contains most of northern Alabama's coal (Ward, 1984) and is located entirely in the Black Warrior Basin; the Coosa and Cahaba coal basins are in the synclinoria of the Appalachian thrust belt. Coals of the Coosa coal basin are primarily in the upper Pottsville Formation. Many coals in the Coosa coal field are shallower than 1,500 ft, and nearly all coals in this field are shallower than 3,000 ft. Cahaba basin coals span nearly the entire Pottsville Formation (McIntyre and Pashin, 2007). Parts of the Cahaba coal field are particularly deep, with coal-bearing strata as deep as 7,000 ft (Hewitt, 1984).

Coals of the Black Warrior Basin are identified as possible targets for carbon dioxide storage because of their great depth. The University of Alabama School of Mines and Energy Development's Duncanville core intersects the Mary Lee and Black Creek coal zones at depths greater than 3,000 ft (Pashin and Raymond, 2004; Pashin and others, 2009). Hatch and Pawlewicz (2007) also depict the Mary Lee, Blue Creek, and Jagger coal fields with areas deeper than 3,000 ft.

Pashin and others (1991) note that some groundwater in the Mary Lee coal zone contains less than $3,000 \mathrm{mg} / \mathrm{L}$ total dissolved solids, which would eliminate this coal as a target for carbon dioxide storage based on EPA standards and recommendations of a minimum $10,000 \mathrm{mg} / \mathrm{L}$ total dissolved solids in groundwater used for carbon dioxide storage projects (EPA, 2010).

The Black Warrior Basin and southern Appalachian thrust belt deep coal polygons surround the locations of wells from NCRDS (U.S. Geological Survey, 2012) and Geological Survey of Alabama data that intersected coal deeper than 3,000 ft and deeper than 1,000 ft. Geological Survey of Alabama researcher Marcella McIntyre-Redden provided the Geological Survey of Alabama deep well data (DeepCoalWells_ALGS.shp) in 2012.

In 2010, SECARB injected 252 metric tons of carbon dioxide into the Pottsville Formation's Pratt, Mary Lee, and Black Creek coals in the Blue Creek coal field, Black Warrior Basin, Tuscaloosa County, Alabama, as part of a field test for carbon dioxide storage in coal with ECBM production. The injection depth was between 940 and 1,800 ft (National Energy Technology Laboratory, 2012; Pashin and others, 2015). 
Preliminary GIS Representation of Deep Coal Areas for Carbon Dioxide Storage in the Contiguous United States and Alaska

\section{Gulf Coast Province}

The coal-bearing strata in the Gulf Coast Province include the Tertiary Claiborne, Jackson, and Wilcox Groups, which dip toward the Gulf of Mexico. Coals are distributed throughout these formations, and individual beds can reach $10 \mathrm{ft}$ thick (Breland, 2004). Ayers and Lewis (1985) reported the depths of Wilcox Group coals ranging from 2,000 to 6,000 ft. The maximum depth of coal in this province is assumed to be the base of the Cretaceous-Tertiary coalbed methane play (Warwick and others, 2007). Wilcox Group coals in east-central Texas, particularly the Calvert Bluff Formation, are targeted for possible carbon dioxide storage (McVay and others, 2007).

The Gulf Coast Province 3,000 ft and 1,000 ft deep coal polygons were created using existing GIS data and represent coal-bearing sections of the Claiborne, Jackson, and Wilcox Groups deeper than 3,000 ft and 1,000 ft. The northern limit of the Gulf Coast Province polygons are the smoothed $-3,000-\mathrm{ft}$ and $-1,000-\mathrm{ft}$ contours of the structure map of the top of the Wilcox Group in the wilcox_top_structure.shp (Warwick, written commun., 2015). The southern boundary of the polygons is the limit of the Cretaceous-Tertiary coalbed gas assessment unit of Warwick and others (2007). The polygons were clipped to the State-waters boundary.

\section{Interior Province}

\section{Illinois Basin}

Illinois Basin coals are of Pennsylvanian age. Prominent coals in this basin include the Springfield and Herrin coals of the Carbondale Formation in Illinois (or of the Petersburg and Dugger Formations, respectively, of the Carbondale Group in Indiana), the Danville coal of the Shelburn Formation in Illinois and of the Dugger Formation in Indiana, and the Baker coal of the Shelburn Formation in Kentucky (Hatch and Affolter, 2002). Illinois Basin cross sections by Treworgy and Whitaker (1990a, 1990b); Treworgy and others (1992); Whitaker and Treworgy (1990); and Whitaker and others (1992a, 1992b) suggest that Pennsylvanian strata do not reach 3,000 ft depth in the Illinois Basin, only approaching 2,000 ft deep at the deepest portions of the middle of the basin.

The polygon representing coal deeper than 1,000 ft in the Illinois Basin was created by selecting the LEGEND attribute of "greater than 1,000 ft" from the ibspovb.shp shapefile of Gunther and others (2002), representing the depth of overburden (ovb) atop the Springfield coal (sp) in the Illinois Basin (ib). The Herrin, Danville, and Baker coals are shallower than the other areas, and their outlines at 1,000 ft deep are entirely inside the 1,000 ft footprint of the Springfield coal.

In 2008, the Midwest Geological Sequestration Consortium (MGSC) injected 92.3 metric tons of carbon dioxide into the Illinois Basin's Springfield coal, Wabash County, Illinois, at between 896 and $902 \mathrm{ft}$ deep as part of the Tanquary ECBM field test (National Energy Technology Laboratory, 2010b; Finley, 2011).

\section{Fort Worth Basin}

Fort Worth Basin coals are considered part of the Interior Province, rather than part of the nearby Gulf Coast Province, because the Ouachita thrust belt separates the two provinces. The coals in the Fort Worth Basin are located in the Pennsylvanian Strawn Group and are scattered and discontinuous, but they could be considered for carbon dioxide storage because many of these coals are deeper than 3,000 ft. Little depth-to-coal information exists for this area because the literature focuses on coals shallower than 3,000 ft. Depth to coal generally increases northwestward in the Fort Worth Basin, with the deepest coalbeds occurring in the Texas Panhandle (Evans, 1974). Mapel (1967) reported coals deeper than 3,000 ft in Cottle, Foard, Hardeman, Motley, and Wilbarger Counties, Texas. Cheney (1940) suggests that the coal-bearing formations of the Strawn Group continue through Young, Archer, and Wichita Counties, Tex., consistent with Mapel's (1967) maps of deep coal distribution. Underlying Atokan rocks in the Texas Panhandle also contain coal deeper than 4,000 ft, but these coals are less continuous than those of the Strawn Group (Mapel, 1967) and are not included in the Fort Worth Basin deep coal polygons.

The primary polygon in the Fort Worth Basin is the result of geoprocessing three data sources: (1) IHS Inc. (2010) well depths to the top of the Strawn Group (Strawn_IHS_tops.shp shapefile), through which a surface model was created using inverse-distance weighted interpolation, and $3,000 \mathrm{ft}$ and $1,000 \mathrm{ft}$ contours were created; (2) scanned and georeferenced figures of coal distribution from Mapel (1967); and (3) the coal fields polygon for the Southwestern Region of the Interior Province from East (2013). The western edge of the 3,000 ft and 1,000 ft Fort Worth Basin polygons is the western edge of the Southwest Region defined by East (2013). The southern boundaries are the 3,000-ft and 1,000-ft contours of the overburden atop the Strawn Group. The eastern edge of the 3,000 ft polygon is bound by Mapel's (1967) Strawn coal boundary, as IHS Inc. (2010) Strawn data do not exist in the area that Mapel claimed to be Strawn coal. The eastern edge of the 1,000 ft polygon is bounded 
by Mapel's (1967) Strawn coal boundary and East's (2013) Fort Worth Basin polygon. The polygons beyond the boundaries of East's (2013) Fort Worth Basin polygon were added to the Fort Worth Basin polygon from a scanned and georeferenced figure of Strawn coal (fig. 7 of Mapel, 1967). Coal boundaries that followed State or county borders were generalized, as Mapel (1967) suggested in the text that these coal areas extend into surrounding counties.

\section{Western Interior Coal Region}

The Western Interior Coal Region contains three coal basins-from north to south, the Forest City, Cherokee, and Arkoma Basins (EPA, 2004b) — which were strip-mined extensively.

Coal in the Forest City Basin, the northernmost basin in the Western Interior Coal Region, is confined to the Middle Pennsylvanian Riverton Formation and the Cherokee, Marmaton, and Pleasanton Groups (Rice and others, 1995). These coals reach a depth of about 1,600 ft (Anderson and Wells, 1968; Rice and others, 1995).

The main coals in the Cherokee Basin are in the Middle Pennsylvanian Krebs and Cabaniss Formations of the Cherokee Group. The EPA (2004b) suggests that these coals are 800-1,200 ft deep, although Dave Newel from the Kansas Geological Survey suggested the Riverton coal of the Krebs Formation and the Weir-Pittsburg coal of the Cabaniss Formation might extend deeper than 2,000 ft in the western parts of the Cherokee Basin (written commun., 2012).

In the Arkoma Basin, coal in the Middle Pennsylvanian Hartshorne Formation and underlying Middle Pennsylvanian Atoka Formation (Iannacchione and others, 1983) extend deeper than 5,000 ft below the surface (EPA, 2004b). Regional cross sections A-A' and B-B' in Andrews (1998) depict the Hartshorne upper and lower coals at about 3,000-3,500 ft deep through Le Flore and Hughes Counties, Oklahoma. Iannacchione and Puglio (1979) show areas of overburden in the 3,000-4,000 ft range in Haskell and Le Flore Counties, Okla. Low groundwater salinity may preclude carbon dioxide storage in some of this area, particularly in Oklahoma (EPA, 2004b). Coalbed thicknesses range from less than a foot to more than 3 feet and are discontinuous in parts of the basin (Houseknecht and Iannacchione, 1982).

The deep coal polygons for the Western Interior Coal Region in the accompanying shapefiles were created using IHS Inc.'s (2010) depth-to-top-of-formation data for both the Atoka and Hartshorne Formations (atoka_tops.shp and hart_IHS_tops.shp shapefiles) in the Arkoma Basin. Surface models were created using inverse-distance weighted interpolation through the points representing the formations' top surfaces, and 3,000-ft contours were created. The polygons enclosed by the 3,000-ft contours were merged and clipped to the Western Region polygon from East (2013). The resulting area encompasses the Hartshorne coal depicted by Iannacchione and Puglio (1979). The 1,000 ft polygons were created using IHS Inc.'s (2010) depth-to-topof-formation data for the Riverton Formation and the Cherokee, Marmaton, and Pleasanton Groups in the Forest City Basin; the Krebs and Cabaniss Formations, Cherokee Group, and Riverton and Weir-Pittsburg coals in the Cherokee Basin and the Chautauqua Basin (the name used in the IHS Inc. database for the portion of the Cherokee Basin in Oklahoma); and the Atoka and Hartshorne Formations in the Arkoma Basin.

\section{Northern Great Plains Province}

\section{Powder River Basin}

The primary coal-bearing formations in the Powder River Basin are the Tertiary Wasatch and Fort Union Formations. Most coalbeds of the Wasatch Formation are about $200 \mathrm{ft}$ deep (Choate and others, 1984). The IHS Inc. (2010) data for coal occurrences deeper than 3,000 ft and 1,000 ft in the Fort Union Formation suggest an area of deep coal that trends northwest-southeast through the Powder River Basin. The thickest Wyodak-Anderson coalbeds are more than $200 \mathrm{ft}$ thick (Luppens and Scott, 2015). Overburden maps by Scott and others (2011) and GIS data from Kinney and others (2015) confirm the extents of these areas of deep coal. Areas where coal exists deeper than $3,000 \mathrm{ft}$ and 1,000 ft in any of the 47 Powder River Basin coalbed layers in the depth-to-coal raster data of Kinney and others (2015) were selected, and these areas were then converted to vector polygons.

\section{Williston Basin}

The primary coal-bearing formation of the Williston Basin is the Paleocene Fort Union Formation, which dips shallowly $\left(1^{\circ}-2^{\circ}\right)$ toward the center of the basin. The Fort Union Formation is subdivided, from bottom to top, into the Ludlow, Cannonball, Tongue River, and Sentinel Butte Members (Ellis and others, 1999b). The majority of this coal is too shallow for carbon dioxide storage, according to depth estimates by Averitt (1975). Ellis and others' (1999b) overburden maps suggest no significant coal deeper than 3,000 ft. Murphy (2006) reported that lignite in the North Dakota section of the Williston Basin 
might extend to $1,800 \mathrm{ft}$ deep or more. A review of cross sections by county suggests that the deepest coal in the Fort Union Formation is around 2,000 ft (Murphy, 2006). Because the Fort Union Formation deepens toward the center of the basin, coals in the basin margins in northern South Dakota and eastern Montana would likely be shallower than those investigated in the counties of western North Dakota by Murphy (2006).

The Williston Basin 1,000 ft coal polygon was created by selecting the polygons with an OVERBURDEN attribute of 1,000-1,500 ft, 1,500-2,000 ft, and 2,000-3,000 ft from the shapefile harovb.shp (U.S. Geological Survey Fort Union Assessment Team, 1999), representing the Harmon coal zone, lowermost Tongue River Member of the Fort Union Formation in the Bowman-Dickinson coal field.

In March 2009, the Plains $\mathrm{CO}_{2}$ Reduction Partnership (PCOR) injected 90 tons of carbon dioxide into a 1,100-ft-deep Fort Union Formation lignite seam in Burke County, North Dakota, part of the Williston Basin (University of North Dakota Energy \& Environmental Research Center, 2014).

\section{Rocky Mountain Province}

\section{Bighorn Basin}

Coal-bearing formations of the Bighorn Basin include the Cretaceous Cloverly, Frontier, Mesaverde, Meeteetse, and Lance Formations; the Paleocene Fort Union Formation; and the Eocene Willwood and Tatman Formations (Roberts and Rossi, 1999). The thickest coals are in the Mesaverde, Meeteestse, and Fort Union Formations (Finn and others, 2009). The coals of the Mesaverde Formation are within non-marine sandstones contained in a regressive marine sequence, and the coals range in thickness from 4 to $12 \mathrm{ft}$ (Finn and others, 2009). The Meeteeste Formation coals occur in alternating thin beds of fine coastal sediments (Finn and others, 2009). Finally, the Fort Union Formation coals occur in alluvial sediments and range in thickness from $3 \mathrm{ft}$ to a rare extreme of $10 \mathrm{ft}$ (Roberts and Rossi, 1999). Coal-bearing strata deepen in the center of the basin and may extend deeper than 15,000 ft (Finn and others, 2009), so coals in the ideal depth range for carbon dioxide injections occur near the edge of the basin.

The Bighorn Basin deep coal polygon was created by first selecting all IHS Inc. (2010) tops data points associated with the Mesaverde, Meeteestse, and Fort Union Formations in the Bighorn Basin (Bighrn_cpts.shp shapefile). Next, a surface model was created using inverse-distance weighted interpolation using the depths to the top of the most data-rich formation-the Mesaverde - and contours were created at 3,000 and 1,000 ft. These contour lines were then converted into polygons.

\section{Wind River Basin}

The primary coal-bearing formations of the Wind River Basin are the Upper Cretaceous Meeteetse, Mesaverde, and Cody Formations; the Lower Eocene Wind River Formation (often combined with the Indian Meadows Formation); and the Paleocene Fort Union Formation (Hogle and Jones, 1991; Flores and Keighin, 1999). The Wind River and Indian Meadows Formations crop out in the basin and are up to 5,500 ft thick, but their coals are lenticular, discontinuous, and limited in extent (Hogle and Jones, 1991). The Fort Union Formation is more continuous and perhaps a better carbon dioxide storage target than the Wind River and Indian Meadows Formations, even though shallower coals in the Wind River and Indian Meadows meet the minimum depth requirements for this report. The accompanying GIS data represent the Fort Union Formation coal areas only.

Fort Union Formation coalbeds are 5-15 ft thick near Castle Gardens, Fremont County, Wyoming. (Flores and others, 1992), although one coalbed in this area is $40 \mathrm{ft}$ thick (Johnson and Flores, 1993). Coalbeds may reach 2 miles in their lateral extent (Flores and others, 1992).

The Wind River Basin polygons in the accompanying deep_coal_us.shp shapefile were created by scanning and georeferencing the Fort Union Formation structure map of Hogle and Jones (1991). The structure contour lines were digitized as vectors, converted to raster data, and subtracted from the Wind River Basin DEM using the raster calculator tool. The resulting overburden contours of $3,000 \mathrm{ft}$ and 1,000 ft were used as the southern boundaries of the deep coal areas in the basin. The northern boundary was the northern edge of the coal field polygon for the Wind River Basin polygon in East's (2013) coal fields shapefile.

\section{Green River Basin}

The EPA (2004d) identified the Paleocene Fort Union Formation and the Upper Cretaceous Mesaverde Group containing the Williams Fork and Almond Formations as the primary coal-bearing formations of the Green River Basin in northwestern Colorado and southern Wyoming. The Eocene Wasatch Formation also contains some coal but may be too shallow for carbon dioxide injections (though it may be included in the deep portions of the Mesaverde Group elsewhere). The Williams Fork Formation deepens southeastward from the surface to $8,000 \mathrm{ft}$ below the surface (EPA, 2004d). Tremain and others (1996) 
suggest most of this region contains coalbeds deeper than 3,000 ft. Jones and others (1978) show this in a coal resources map of the Colorado portion of the Green River area representing deep areas of the Mesaverde Group (Lance, Fort Union, and Wasatch Formations) in Moffat and Routt Counties, Colorado.

NCRDS data (U.S. Geological Survey, 2012) contain information on wells intersecting coalbeds deeper than 3,000 ft in the following formations with corresponding coalbed thickness ranges: Almond Formation (1-7 ft), Fort Union Formation (2-50 ft), Fox Hills Sandstone (1-5 ft), Frontier Formation (3 ft), Lance Formation (1-22 ft), Wasatch Formation (4-16 ft), Williams Fork Formation (10-29 ft) and the Mesaverde Group (1-36 ft). When evaluated collectively, NCRDS records suggest coal-bearing strata reach depths of at least 11,000 ft in this basin. The formations in NCRDS do not closely match formation names in IHS Inc. (2010).

Areas of coal deeper than $3,000 \mathrm{ft}$ and 1,000 ft in the far southeastern part of the Green River Basin region were obtained from the NCRA shapefiles yama_fin.shp, yamb_fin.shp, yamc_fin.shp, and yamd_fin.shp, representing the overburden over the Yampa coal field zone A, B, C, and D, respectively (U.S. Geological Survey Fort Union Assessment Team, 1999). The attribute OVERB, in units of hundreds of $\mathrm{ft}$ of overburden, was used to create the polygons. To create the polygons for the rest of the Green River Basin, IHS Inc. (2010) wells in this basin (GreenRiv_tops.shp shapefile) that intersected the Fort Union, Almond, and Williams Formations were selected and used to interpolate depth-to-top surface models for each formation individually. These surface models were contoured, and the areas containing coal deeper than 3,000 $\mathrm{ft}$ were added to the Green River Basin 3,000-ft polygon; the areas containing coal deeper than 1,000 ft that were not already in the 3,000-ft polygon were put into the 1,000-ft polygon. The same was done for the Danforth Hills coal field, coal zones A, B, C, D, E, F, and G (dana_fin.shp through dang_fin.shp; U.S. Geological Survey Fort Union Assessment Team, 1999).

\section{Hanna and Carbon Basins}

The Hanna and Carbon Basins, Wyo., contain coalbeds up to $36 \mathrm{ft}$ thick in fluvial sediments of the Upper Cretaceous Ferris Formation and overlying Tertiary Hanna Formation (Ellis and others, 1999a; Flores and others, 1999a).

The deep coal polygons of the Hanna and Carbon Basins resulted from selecting, exporting, and merging the NCRA polygons for coal zones with overburdens of 3,000-4,000 ft; 4,000-5,000 ft; and 5,000-10,000 ft (the > 3,000 ft polygon), and $1,000-1,500 \mathrm{ft} ; 1,500-2,000 \mathrm{ft}$; and 2,000-3,000 ft (the 1,000-3,000 ft polygon). The relevant NCRA shapefiles for this step were fer23ovb.shp, fer25ovb.shp, fer31ovb.shp, fer50ovb.shp, fer65ovb.shp, ha77ovb.shp, ha78ovb.shp, ha79ovb.shp, ha79ovb. shp, and ha81ovb.shp (U.S. Geological Survey Fort Union Assessment Team, 1999).

\section{Raton Basin}

The primary coal-bearing formations of the Raton Basin in northeastern New Mexico and southeastern Colorado are the Upper Cretaceous Vermejo Formation and overlying Cretaceous and Paleocene Raton Formation (Johnson and Finn, 2001). Coal is more prevalent in the Vermejo Formation than the Raton Formation (Dolly and Meissner, 1977), but the coalbeds of the Vermejo Formation ( 6 in. to $6 \mathrm{ft}$ ) are thinner than the coalbeds of the Raton Formation (6 in. to $12 \mathrm{ft}$ ) (Dolly and Meissner, 1977). The depth of overburden ranges from $500 \mathrm{ft}$ to about $4,000 \mathrm{ft}$ for the Vermejo Formation, deepening from southeast to northwest. All of the groundwater of the greater Raton Basin is fresher than 10,000 mg/L total dissolved solids (EPA, 2004c).

The boundaries of the deep coal area were digitized from the overburden to coal interval figure of Stevens and others (1992). The $1,000 \mathrm{ft}$ contour was created by interpolating between the 800 - and 1,100-ft contours and the 3,000-ft contour was created by interpolating between the 2,900- and 3,200-ft contours.

\section{San Juan Basin}

The primary coal-bearing formations of the San Juan Basin, New Mexico, are the Cretaceous Menefee Formation and the Upper Cretaceous Fruitland Formation. The Fruitland Formation contains coalbeds $20-80 \mathrm{ft}$ thick (EPA, 2004a) and extends to $4,500 \mathrm{ft}$ deep (Shomaker and Whyte, 1977). NCRDS well data (U.S. Geological Survey, 2012), however, suggest that coal was first intersected at a 5,228 ft depth for a well with a total depth of around 8,000 ft, and thicknesses are from less than $1 \mathrm{ft}$ to $72 \mathrm{ft}$. According to selected NCRDS wells for the Menefee Formation, coal-bearing strata reach 6,357 ft deep with bed thicknesses ranging from 1 to $18 \mathrm{ft}$. The Menefee Formation contains beds at least $2 \mathrm{ft}$ thick extending 6,000 ft below the surface (Shomaker and Whyte, 1977). The NCRDS and IHS Inc. (2010) data regarding depth to the tops of the coal-bearing formations agree with the literature in depicting a thickening of overburden in the northeastern part of the basin (in the area around Rio Arriba, northeastern San Juan, and southwestern La Plata Counties, N. Mex.). The Fruitland Formation has been heavily mined and developed for coalbed methane production. Groundwater in the northwest and southwest parts of the San Juan Basin has total dissolved solids concentrations of more than $10,000 \mathrm{mg} / \mathrm{L}$; the southeastern area is less saline and can contain less than $10,000 \mathrm{mg} / \mathrm{L}$ total dissolved solids in some locations (EPA, 2004a). 
Areas corresponding to overburdens of from 1,000 to 3,000 ft and more than 3,000 ft over the base of the Fruitland Formation were selected from the NCRA shapefile for the San Juan Basin - sjb_fin.shp; attribute OVERB of 10-20 and 20-30 and OVERB of $>30$, respectively. The units for overburden thickness in the shapefile are hundreds of feet (U.S. Geological Survey Colorado Plateau Coal Assessment Team, 2000).

The first ECBM carbon dioxide injection occurred in 1995 in the San Juan Basin, San Juan County, N. Mex., into a 43-ft coalbed of the Fruitland Formation at 3,100 ft depth. From 1995 to 2001, when injection ceased, 322,000 metric tons of carbon dioxide were injected, and the coal retained 277,000 metric tons of the carbon dioxide; the rest was coproduced with methane (Intergovernmental Panel on Climate Change, 2005).

\section{South Park Basin}

Jones and others' (1978) map depicts the majority of the South Park Basin, Colo., as containing coal beneath at least 3,000 ft of overburden. Eakins (1986) reports that the coals of the Upper Cretaceous Laramie Formation in the South Park Basin are deeper than 3,000 ft. Coalbeds in the Laramie Formation are between 1 and $5 \mathrm{ft}$ thick (Washburne, 1910).

Areas of coal with more than 3,000 ft of overburden were digitized from the South Park Basin area in the map by Jones and others (1978).

\section{Denver Basin}

The two coal-bearing formations of the Denver Basin are the Upper Cretaceous Denver and Laramie Formations (Tremain and others, 1996). Dechesne and others (2011) published a GIS layer of structure contours showing the elevation of the top of the Fox Hills Sandstone, the unit directly underlying the coal-bearing units of the Denver Basin. This vector layer was converted to raster, subtracted from a regional DEM, and the resulting raster of depth-to-top of the Fox Hills Sandstone was contoured at overburdens of $3,000 \mathrm{ft}$ and $1,000 \mathrm{ft}$.

\section{Kaiparowits Plateau}

The primary coal-bearing unit of the Kaiparowits Plateau, Utah, is the John Henry Member of the Upper Cretaceous Straight Cliffs Formation (Hettinger, 2009). The deepest sections occur in the middle of the basin and extend deeper than 6,000 $\mathrm{ft}$ below the surface. The John Henry Member contains eleven coalbeds more than $4 \mathrm{ft}$ thick (Vaninetti, 1979).

Areas corresponding to overburden of 1,000-3,000 ft or more than 3,000 ft over the base of the Calico sequence and A-sequence were selected from NCRA shapefiles for the southern Wasatch Plateau—kai_tfin.shp and kaintfin.shp; attribute OVERB of 1-2 and 2-3 and OVERB of 3-6 and $>6$, respectively. The units for overburden thickness in the shapefile are thousands of feet (U.S. Geological Survey Colorado Plateau Coal Assessment Team, 2000).

\section{Henry Mountains}

Coal in the Henry Mountains coal field, Utah, is primarily in the Ferron Sandstone Member and the Muley Canyon Sandstone Member of the Upper Cretaceous Mancos Shale. Although the Dakota Sandstone is also coaliferous here, its coals are insignificant. The Ferron Sandstone Member's coalbeds average 1-3 ft thick, with an aggregate thickness of up to $16.5 \mathrm{ft}$. However, the total coal thickness is less than $2 \mathrm{ft}$ across much of the basin. The Muley Canyon Sandstone Member's coals are thicker than those of the Ferron Sandstone Member - typically 2-5 ft thick within individual beds and up to $27.5 \mathrm{ft}$ thick in aggregate. The Ferron Sandstone Member is deeper than the Muley Canyon Sandstone Member. The Ferron Sandstone Member coals extend to deeper than 2,000 ft, but the Muley Canyon Sandstone Member coals are almost all shallower than 1,000 ft (Tabet, 2000).

A polygon corresponding to the area of the Ferron Sandstone Member coal zone deeper than 1,000 $\mathrm{ft}$ was digitized from figure 7 in Tabet (2000).

\section{Uinta Region}

The principal coal-bearing strata of the Uinta Region, in Utah and Colorado, are the Upper Cretaceous Mesaverde Group (Tremain and others, 1996; Kirschbaum and others, 2000) and, in Colorado, the Upper Cretaceous Dakota Sandstone. The Mesaverde Group's main coal-bearing layers are the Iles and Williams Fork Formations (Kirschbaum and others, 2000). Most of the eastern Uinta Region is covered by more than $3,000 \mathrm{ft}$ of overburden (Jones and others, 1978). 
The primary coal-bearing formation of the Wasatch Plateau, on the far western edge of the Uinta Region, is the Upper Cretaceous Blackhawk Formation, which may extend deeper than 5,000 ft (Dubiel, 2000). Coals on the Wasatch Plateau may occur even deeper in the Ferron Sandstone Member and Emery Sandstone Member of the Cretaceous Mancos Shale. East of the Wasatch Plateau, the Emery coal field contains the upper and lower Ferron coals (Ryer, 1981). These deep coals are in the Ferron Sandstone Member of the Mancos Shale and have a net thickness of $24 \mathrm{ft}$ (Dallegge and Barker, 2000). The polygon for this area in the accompanying map was made by creating a surface using interpolation of available IHS Inc. (2010) well data. These and other areas of deep coal in the Utah portion of the Uinta-Piceance Basin should be reexamined when more depth information is available.

NCRDS data (U.S. Geological Survey, 2012) for wells that intersect coalbeds at least 3,000 ft below the surface are primarily concentrated in the Colorado (eastern) side of the Uinta-Piceance Basin. These records represent substantial deep coalbeds in the following strata with corresponding ranges of bed thicknesses: Corcoran Member of the Mount Garfield Formation of the Mesaverde Group (1-12 ft), Cozzette Formation (1-8 ft), Mesaverde Formation (1-45 ft), Mesaverde Group (1-52 ft). However, IHS Inc. (2010) and NCRDS formation names and field names correspond poorly in the basin.

Data from IHS Inc. (2010) and the U.S. Geological Survey Colorado Plateau Coal Assessment Team (2000) were combined to create the Uinta Basin deep coal polygons.

Areas corresponding to overburdens of 1,000-3,000 ft, and more than 3,000 ft over the base of the Blackhawk Formation, were selected from the NCRA shapefile for the southern Wasatch Plateau-ws_fin.shp; attribute OVERB of 10-20 and 20-30 and OVERB of $>30$, respectively. The units for overburden thickness in the shapefile are hundreds of feet (U.S. Geological Survey Colorado Plateau Coal Assessment Team, 2000). Areas corresponding to overburdens of 1,000-3,000 ft and more than $3,000 \mathrm{ft}$ over the base of the Cameo-Fairfield coal group (east of $107^{\circ} 15^{\prime} \mathrm{W}$ longitude, pscb_fin.shp) and the Cameo-Wheeler coal zone (west of $107^{\circ} 15^{\prime} \mathrm{W}$ longitude, pscw_fin.shp) were selected from the NCRA data shapefiles for the Piceance Basinattribute OVERB of 10-20 and 20-30 and OVERB of $>30$, respectively (U.S. Geological Survey Colorado Plateau Coal Assessment Team, 2000). Areas corresponding to overburdens of 1,000-3,000 ft and more than $3,000 \mathrm{ft}$ over the base of the South Canyon and Coal Ridge coal zones were selected from the NCRA shapefiles for the Piceance Basin_ pssc_fin.shp, pscr_ fin.shp; attribute OVERB of 10-20 and 20-30 and OVERB of >30, respectively, (U.S. Geological Survey Colorado Plateau Coal Assessment Team, 2000). Areas corresponding to overburden of more than 1,000 ft over the base of the B and D coal fields of the Lower White River coal field, Deserado coal assessment area, were selected from NCRA shapefiles desb_fin.shp and desd_fin.shp, respectively (attribute OVERB of $>10$ ). The units for overburden thickness in the shapefile are hundreds of feet (U.S. Geological Survey Colorado Plateau Coal Assessment Team, 2000).

The eastern section of the Uinta Region's deep coal polygons was created by combining NCRA overburden estimates and the Jones and others (1978) map of the depth to bituminous coal occurrences deeper than 3,000 ft. Areas corresponding to overburden categories of more than 3,000 ft in NCRA data (U.S. Geological Survey Colorado Plateau Coal Assessment Team, 2000) for the Alton coal field and the Wasatch Plateau coal field (Blackhawk Formation) were selected and added to the Uinta Basin deep coal polygons.

IHS Inc. (2010) tops data were used to create the portions of the Utah sections of the Uinta-Piceance Basin. IHS Inc. (2010) tops data for the Ferron coal and Mesaverde Formation were selected from the UintaP-IHS_tops.shp shapefile. An interpolated surface model was created for the Mesaverde Formation, and contours of 3,000 ft and 1,000 ft were created and exported. These lines were converted into polygons. All shapefiles were merged to create the final polygons.

\section{Pacific Coast Province}

Coals west of the Cascade Range are intensely deformed, with steep northwestward dips and an increasing coal rank from west to east (Choate and Johnson, 1980). Michael Brownfield (USGS, written commun., 2012), an expert on the region's geology, suggested coal in Washington deeper than 3,000 ft occurs in the Bellingham Basin. Additional literature searches led to the inclusion of additional coal fields in Washington: Glacier coal field in Whatcom County, Green River coal field in King County, and the Wilkeson-Carbonado coal field in Pierce County. Cowlitz County, Washington, was not considered because of a lack of information in the geologic literature. Due to a lack of specific depth-to-coal information, the entire shape of each Washington and Oregon coal field from East (2013) was used to delineate areas of coal deeper than 3,000 ft in the Oregon and Washington coal basins detailed below.

\section{Bellingham Basin and Glacier Coal Field}

The primary coal-bearing formations of the Bellingham Basin are the Huntingdon and underlying Chuckanut Formations of Eocene alluvial deposits (Choate and Johnson, 1980); the most extensive coals occur in the Chuckanut Formation (Brownfield, 2011). These units are significantly deformed and deepen away from the western edge of the Cascade Range 
(Choate and Johnson, 1980). The Chuckanut Formation contains 15 coalbeds ranging from 1 to $15 \mathrm{ft}$ thick (EPA, 2004e). The entire formation is over 19,000 ft thick in its deepest basins and contains coal in the lowest member, the Bellingham Bay Member. Walsh and Phillips (1983) estimate an overburden thickness of more than 20,000 ft. The coal areas in Skagit County, Wash., were included with the Bellingham Basin. These areas share the same coal-bearing formation (Walsh and Phillips, 1983), although the literature is silent concerning these areas in Skagit County. The Glacier coal field is east of the Bellingham Basin and shares the same coal-bearing formation; much of the coal is anthracite (Woodruff, 1914).

The Jordan Exploration Company, LLC, investigated storing carbon dioxide storage in coalbeds of the Huntingdon and Chuckanut Formations before 2009 (Stevens, 2009). The project did not proceed, however, because of the considerable distance to carbon dioxide sources and the regional structural deformation of coal-bearing sediments (U.S. Department of Energy, 2010).

\section{Wilkeson-Carbonado Coal Field}

The Wilkeson-Carbonado coal field appears to contain coal deeper than 3,000 ft (Choate and Johnson, 1980), but this should be investigated further with additional depth information, as an expert on the region, Michael Brownfield, did not suggest this area as a possible target for carbon dioxide storage (USGS, written commun., 2012). The coal-bearing formation in this coal field is the Eocene Carbonado Formation and consists of over 5,000 ft of interbedded sandstone, siltstone, mudstone, shale, and coal. Its ten coalbeds are each 1-15 ft thick. The Carbonado Formation is intensely deformed, with fault displacements of up to $1,500 \mathrm{ft}$ (EPA, 2004e). The Carbonado Formation lies beneath more than 11,000 ft of sedimentary and volcanic rocks (Choate and Johnson, 1980).

\section{Green River Coal Field}

The Green River coal field in King County, Wash., appears to contain coal deeper than 3,000 ft (Choate and Johnson, 1980). However, this should be investigated further with additional depth information, as an expert on the region, Michael Brownfield, did not suggest this area as a possible target (USGS, written commun., 2012). The coal-bearing stratum of the Green River coal field is the undifferentiated Eocene Puget Group, which is divided into the Bayne, Franklin, and Kummer coal zones (Evans, 1912; EPA 2004e). The Puget Group contains at least 12 coalbeds ranging in thickness between 3 and $40 \mathrm{ft}$ (Choate and Johnson, 1980) and the coals rank from subbituminous to high-volatile bituminous (EPA, 2004e). Coal was mined historically from a depth of 4,000 ft in part of this field (Philips and Walsh, 1981).

\section{Coos Bay Field}

The coal-bearing formation of Oregon's Coos Bay coal field is the Eocene Coaledo Formation, which thins from around $6,000 \mathrm{ft}$ thick in the east to around 3,000 ft thick in the west (Duncan, 1953). Coal occurs in both the upper and lower Coaledo Formation (Ehlen, 1967). According to regional cross sections by Black and Madin (1995), the Coaledo Formation is deeper than $3,000 \mathrm{ft}$ on the far western edge of the field. Coalbeds of the Coaledo Formation range from less than an inch to $19 \mathrm{ft}$ thick (Sidle, 1981)

\section{North Slope (Alaska) Province}

\section{North Slope}

The North Slope (Alaska) Province contains deep Mississippian coal deposits up to 5 feet thick (Clough and Stricker, 1994), but little is known about its lateral continuity due to a lack of well data at these depths. The primary Mississippian-age field is in the Lisburne mining district (Collier, 1906; Martin, 1907).

Of the Cretaceous coal-bearing rocks, the most substantial are the Lower Cretaceous Nanushuk Formation and the Upper Cretaceous Prince Creek Formation. The Nanushuk Formation comprises marine and coal-bearing non-marine strata; formerly called the Corwin and Killik tongue of the Chandler Formation (Sable and Stricker, 1987); and has a maximum thickness of 9,800 ft. The Nanushuk Formation coal is confined to nonmarine sediments that interfinger with marine sediments. The Upper Cretaceous section has a maximum thickness of 5,000 ft and contains the Seabee, Schrader Bluff, and coal-bearing Prince Creek Formations (formerly of the Colville Group). The coals of the Prince Creek Formation are thinner, contain more ash, and have been less of a focus for economic development than those of the Nanushuk Formation. 
The polygons for the Colville Group and Nanushuk Formation (primarily Corwin Formation), the primary coal-bearing groups, unit attributes Kc and Kco, were selected from Merritt and Hawley's (1986) coalunit_poly.shp shapefile. Scarce well data prevented further depth analyses. The North Slope should be reexamined in more detail as a target for carbon dioxide storage if additional depth-to-coal information can be found.

\section{Southern Alaska-Cook Inlet Province}

\section{Nenana Coal Field}

The Nenana coal field is the largest field in the Southern Alaska-Cook Inlet Province. Its coal is mainly in the Healy Creek, Suntrana, and Lignite Creek Formations of the Tertiary Usibelli Group, and ranges from lignite to subbituminous. Coalbeds in the Oligocene to middle Miocene Healy Creek Formation are up to $65 \mathrm{ft}$ thick. The middle Miocene Suntrana Formation contains six major coalbeds, individually up to $65 \mathrm{ft}$ thick. The middle to late Miocene Lignite Creek Formation contains only relatively thin coalbeds, less than $4 \mathrm{ft}$ thick (Wahrhaftig and others, 1994).

The Nenana coal field polygons were created by digitizing figure 15 of Wahrhaftig and others (1994) and selecting the areas where coalbed no. 6 of the Suntrana Formation - the most significant coalbed in the Nenana coal field — is beneath 1,000-3,000 ft of overburden.

\section{Cook Inlet Basin}

The Cook Inlet Basin's most substantial coal-bearing formation, the Miocene Tyonek Formation of the Kenai Group, ranges in depth from immediately below Quaternary glacial sediments in the Matanuska Valley to more than 10,000 ft below the surface in the middle of the basin. The entire Kenai Group is 26,000 ft thick (Calderwood and Fackler, 1972). The beds of the Tyonek Formation are 50-300 ft thick (Montgomery and others, 2003). There are additional overlying Tertiary coalbearing formations including the Beluga and Sterling Formations, but their coalbeds are thinner than the coalbeds of the Tyonek Formation (Carter and Adkison, 1972). The areas included in this analysis are subbituminous in rank.

In the Cook Inlet Basin, The Tyonek unit polygons were selected from Merritt and Hawley's (1986) coalunit poly. shp shapefile including unit codes Tku, Tt, Ttt, and Tu. These were intersected with the Alaska coal basin polygons from Tewalt and others (2008) of the Cook Coal Basin (AK_coal_shapes.shp shapefile). Finally, to obtain depth information, a surface model was created using IHS Inc. (2010) tops data using the inverse distance weighted interpolation tool. Contours of $1,000 \mathrm{ft}$ were created, integrated, and used to split the original Cook coal basin polygons into polygons of 1,000-3,000 ft depth and greater than $3,000 \mathrm{ft}$ depth.

\section{Areas with Insufficient Deep Coal for Carbon Dioxide Storage}

A preliminary investigation using 3,000 ft and 1,000 ft depth requirements for carbon dioxide storage without ECBM recovery and with ECBM recovery, respectively, eliminated the basins listed below as targets for future assessments of carbon dioxide storage. These areas are not included in the accompanying shapefiles.

\section{Interior Province}

\section{Michigan Basin}

Michigan Basin coal is shallower than the required minimum depth for carbon dioxide storage. Wanless and Shideler (1975) identified the deepest coal-bearing formation as the Pennsylvanian Saginaw Formation based on the lack of fossil flora below the Saginaw coalbed. The base of the Saginaw Formation is less than 1,000 ft deep (Stark and McDonald, 1980), and Swezey and others (2015) reported that drilling depths to coalbeds were less than $800 \mathrm{ft}$. 


\section{Northern Great Plains Province}

\section{Bull Mountain Coal Field}

The Paleocene Fort Union Formation in the Bull Mountain coal field, Montana, lies beneath less than $500 \mathrm{ft}$ of overburden (Conner, 1988), and each bed ranges from less than $1 \mathrm{ft}$ to $17 \mathrm{ft}$ thick (Stricker, 1999). Additionally, the coalbeds discussed by Woolsey and others (1917) were all on the order of hundreds of feet below the surface. The deepest coalbed in this area is the Big Dirty, in the Lebo Shale Member of the Fort Union Formation (Stricker, 1999), with an overburden of slightly over $200 \mathrm{ft}$ (Colorado School of Mines Research Institute, 1978).

\section{North-Central Region}

The coal of the North-Central region of the Northern Great Plains Province is scattered and discontinuous unlike the thick, continuous coalbeds of eastern Montana (Combo and others, 1949). The North-Central region, in western Montana, contains the Great Falls coal field, the Blackfeet-Valier area, and the Flathead coal field. Partly because of its discontinuous character, coal in this region was considered unsuitable for carbon dioxide storage and not mapped as part of this project.

The coal-bearing formation of the Great Falls coal field is the lower Cretaceous Kootenai Formation, which has a local coal zone of multiple beds ranging from 2 to $4 \mathrm{ft}$ thick, occurring around $60 \mathrm{ft}$ above the base of the formation (Barnett, 1917). IHS Inc. (2010) tops data suggest that the Kootenai Formation does not reach 3,000 ft below the surface until areas of the Bull Mountain field to the southeast, the Blackfeet-Valier area to the northwest, or the North-Central region to the north.

The Blackfeet-Valier area contains two coal-bearing formations, both Cretaceous in age: the St. Mary River and the deeper Two Medicine Formations. Thin coalbeds exist $250 \mathrm{ft}$ above the base of the Two Medicine Formation, which is up to 2,200 ft thick (Berg, 2002). However, none of the coalbeds in the five coal zones in the Blackfeet area are thicker than $2 \mathrm{ft}$ (Balster and others, 1976). Valier coal zone bed-thickness averages about 38 inches (Balster and others, 1976). No IHS Inc. (2010) wells intercepted these formations at deeper than 3,000 ft in the Blackfeet-Valier area. Balster and others (1976) reported that the east side of the Blackfeet field dips steeply, sending coalbeds deeper than "minable depths," but this depth was not quantified.

The Flathead coal field contains Upper Cretaceous coal, but Ferguson (1906) gave no depth estimates. No IHS Inc. (2010) data exist for this field.

\section{Rocky Mountain Province}

\section{Black Mesa Coal Field}

Coal in the Black Mesa coal field, northeastern Arizona, is primarily in the Cretaceous-age Dakota, Toreva, and Wepo Formations, and most of it is shallow, covered by less than 1,000 ft of overburden (Nations and others, 2000).

\section{Pacific Coast Province}

\section{Centralia and Roslyn Coal Fields}

Coal in the Centralia coal field in Thurston and Lewis Counties, Wash., occurs in the Skookumchuck Formation, which is covered by less than about 1,500 ft of overburden (Walsh and Philips, 1983). For this reason, the Centralia coal field was not included in this report as a potential target for carbon dioxide storage, despite a West Coast Regional Carbon Sequestration Partnership (WESTCARB) carbon dioxide storage potential study of the location. WESTCARB's depth requirements-from $300 \mathrm{ft}$ to $1000 \mathrm{ft}$-were in large part shallower than those in this investigation (Stevens, 2009). As of 2010, no test injections of carbon dioxide had occurred in the Centralia coal field (National Energy Technology Laboratory, 2010a).

Similarly, the coal in the Roslyn coal field (Kittitas County, Wash.) in the Eocene Roslyn Formation is only about 1,700 ft below the surface (Walsh and Phillips, 1983) and is not included in this report as a potential target for carbon dioxide storage. 


\section{Oregon Coal Fields and Basins}

The coals of the Eden Ridge coal field and Rogue River Basin occur in the Eocene Tyee and Umpqua Formations, respectively (Brownfield, 2011). It is unlikely that coal deeper than 3,000 ft exists in either, as neither was suggested by Brownfield (USGS, written commun., 2012). The base of the Tyee Formation is about 1,500 ft deep (Wayland, 1965). The Umpqua Formation, however, is the deepest coal-bearing formation in western Oregon and should be investigated further.

\section{Acknowledgments}

Comments and suggestions from Joseph East and Philip Freeman (USGS) helped improve this report.

\section{References Cited}

Anderson, K.H., and Wells, J.S., 1968, Forest City Basin of Missouri, Kansas, Nebraska, and Iowa: American Association of Petroleum Geologists Bulletin, v. 52, no. 2, p. 264-281. [Also available at https://doi.org/10.1306/5d25c2cb-16c1-11d78645000102c1865d.]

Andrews, R.D., 1998, Overview of the Hartshorne play in Oklahoma, pt. I of Andrews, R.D., Cardott, B.J., and Storm, T., The Hartshorne play in southeastern Oklahoma - Regional and detailed sandstone reservoir analysis and coalbed-methane resources: Oklahoma Geological Survey Special Publication 98-7, p. 1-40. [Also available at http://www.ogs.ou.edu/ pubsscanned/SPs/SP98_7wm.pdf.]

Averitt, P., 1975, Coal resources of the United States, January 1, 1974: U.S. Geological Survey Bulletin 1412, 131 p. [Also available at https://pubs.er.usgs.gov/publication/b1412.]

Ayers, W.B., Jr., and Lewis, A.H., 1985, The Wilcox Group and Carrizo Sand (Paleogene) in east-central Texas—Depositional systems and deep-basin lignite: Bureau of Economic Geology, University of Texas at Austin, 19 p., 30 pls.

Balster, C.A., Berg, R.B., McClernan, H.G., Hansen, M., Sokaski, M., and McIntyre, G., 1976, Status of mineral resource information for the Blackfeet Indian Reservation, Montana: Bureau of Indian Affairs Administrative Report BIA-24, 69 p., accessed August 29, 2017, at http://www1.eere.energy.gov/tribalenergy/guide/pdfs/blackfeet_24.pdf.]

Barnett, V.H., 1917, Contributions to economic geology, 1916, part II, mineral fuels - Geology of the Hound Creek district of the Great Falls coal field, Cascade County, Montana: U.S. Geological Survey Bulletin 641-H, p. 215-231, accessed August 29, 2017, at https://pubs.er.usgs.gov/publication/b641H.

Berg, R.B., 2002, Geologic map of the Valier 30' $\times 60^{\prime}$ quadrangle, northwestern Montana: Montana Bureau of Mines and Geology Open-File Report MBMG 453, 10 p., 1 sheet, scale 1:100,000, accessed August 29, 2017, at http://www.mbmg.mtech.edu/mbmgcat/public/ListCitation.asp?pub_id=11325\&.

Black, G.L., and Madin, I.P., 1995, Geologic map of the Coos Bay quadrangle, Coos County, Oregon: State of Oregon Geological Map Series 97, 1 sheet, scale 1:24,000. [Also available at http://www.oregongeology.org/pubs/gms/GMS-097.pdf.]

Breland, F.C., Jr., 2004, Coalbed methane potential in Louisiana, in Warwick, P.D., ed., Selected presentations on coal-bed gas in the eastern United States: U.S. Geological Survey Open-File Report 2004-1273, p. 27-35, accessed August 29, 2017, at https://pubs.usgs.gov/of/2004/1273.]

Brownfield, M.E., 2011, Total petroleum systems and geologic assessment of undiscovered hydrocarbon resources of the Western Oregon and Washington Province, chap. 2 of U.S. Geological Survey Western Oregon and Washington Province Assessment Team, Geologic assessment of undiscovered hydrocarbon resources of the Western Oregon and Washington Province: U.S. Geological Survey Digital Data Series DDS-69-X, 100 p., accessed August 29, 2017, at https://pubs.usgs.gov/ dds/dds-069/dds-069-x.

Calderwood, K.W., and Fackler, W.C., 1972, Proposed stratigraphic nomenclature for Kenai Group, Cook Inlet Basin, Alaska: American Association of Petroleum Geologists Bulletin, v. 56, no. 4, p. 739-754, accessed August 29, 2017, at https://doi.org/10.1306/819a407e-16c5-11d7-8645000102c1865d. 
Carter, R.D., and Adkison, W.L., 1972, Correlation of subsurface Tertiary rocks, Cook Inlet Basin, Alaska: U.S. Geological Survey Open-File Report 72-64, 8 p. [Also available at https://pubs.er.usgs.gov/publication/ofr7264.]

Cheney, M.G., 1940, Geology of north-central Texas: American Association of Petroleum Geologists Bulletin, v. 24, no. 1, p. 65-118. [Also available at https://doi.org/10.1306/3d933192-16b1-11d7-8645000102c1865d.]

Choate, R., and Johnson, C.A., 1980, Western Washington coal region report—A study of early Tertiary geology, coal and coalbed methane regions in western Washington: Lakewood, Colo., TRW Energy Systems Group, 154 p.

Choate, R., Johnson, C.A., and McCord, J.P., 1984, Geologic overview, coal deposits, and potential for methane recovery from coalbeds—Powder River Basin, in Rightmire, C.T., Eddy, G.E., and Kirr, J.N., eds., Coalbed methane resources of the United States: American Association of Petroleum Geologists, Studies in Geology Series 17, p. 335-351. [Also available at http://archives.datapages.com/data/bulletns/1938-43/data/pg/0024/0001/0050/0065.htm?doi=10.1306\%2F3D933192-16B111D7-8645000102C1865D.]

Clough, J.G., and Stricker, G.D., 1994, Coal resources of the Colville mining district, central North Slope, Alaska: Division of Geological and Geophysical Surveys, Alaska Department of Natural Resources, Public Data File 94-26, 15 p. [Also available at https://doi.org/10.14509/1651.]

Collier, A.J., 1906, Geology and coal resources of the Cape Lisburne region, Alaska: U.S. Geological Survey Bulletin 278, 54 p., accessed August 29, 2017, at https://pubs.er.usgs.gov/publication/b278.

Colorado School of Mines Research Institute, 1978, Coal resource occurrence and coal development potential maps of the McKerlich Creek Quadrangle, Rosebud County, Montana: U.S. Geological Survey Open-File Report 78-641, 15 p., 9 maps, accessed August 29, 2017, at https://pubs.er.usgs.gov/publication/ofr78641.

Combo, J.X., Brown, D.M., Pulver, H.F., and Taylor, D.A., 1949, Coal resources of Montana: U.S. Geological Survey Circular 53, 28 p., accessed August 29, 2017, at https://pubs.er.usgs.gov/publication/cir53.

Conner, C.W., 1988, Maps showing outcrop, structure contours, cross sections, and isopachs of partings-Mammoth coal bed, Paleocene Tongue River Member of the Fort Union Formation, Bull Mountain coal field, south-central Montana: U.S. Geological Survey Coal Investigations Map 126-A, 4 maps on 2 sheets, accessed August 29, 2017, at https://pubs.er.usgs.gov/publication/coal126A.

Dallegge, T.A., and Barker, C.E., 2000, Coal-bed methane gas-in-place resource estimates using sorption isotherms and burial history reconstruction-An example from the Ferron Sandstone Member of the Mancos Shale, Utah, chap. L of Kirschbaum, M.A., Roberts, L.N.R., and Biewick, L.R.H., eds., Geologic assessment of coal in the Colorado PlateauArizona, Colorado, New Mexico, and Utah: U.S. Geological Survey Professional Paper 1625-B [CD-ROM, also available at https://pubs.usgs.gov/pp/p1625b.]

Dechesne, M., Raynolds, R.G., Barkmann, P.E., and Johnson, K.R., 2011, Notes on the Denver Basin geologic maps—Bedrock geology, structure, and isopach maps of the Upper Cretaceous to Paleogene strata between Greeley and Colorado Springs, Colorado: Colorado Geological Survey Open-File Report OF-11-01, 1 booklet with DVD.

Dolly, E.D., and Meissner, F.F., 1977, Geology and gas exploration potential, Upper Cretaceous and Lower Tertiary strata, northern Raton Basin, Colorado, in Veal, H.K., ed., Exploration frontiers of the central and southern Rockies: Denver, Colo., Rocky Mountain Association of Geologists guidebook, 1977 Symposium, 27th field conference, p. 247-270. [Also available at http://archives.datapages.com/data/rmag/ExplorFrontRock77/dolly.htm.]

Dubiel, R.F., 2000, Summary of geology and coal resources of the Blackhawk Formation in the southern Wastach Plateau, central Utah, chap. K of Kirschbaum, M.A., Roberts, L.N.R., and Biewick, L.R.H., eds., Geologic assessment of coal in the Colorado Plateau—Arizona, Colorado, New Mexico, and Utah: U.S. Geological Survey Professional Paper 1625-B, [CD-ROM, also available at https://pubs.usgs.gov/pp/p1625b.]

Duncan, D.C., 1953, Geology and coal deposits in part of the Coos Bay coal field, Oregon: U.S. Geological Survey Bulletin 982-B, 73 p., accessed August 29, 2017, at https://pubs.er.usgs.gov/publication/b982B.

Eakins, W., 1986, Coal resources of the Colorado Springs $1 / 2^{\circ} \times 1^{\circ}$ Quadrangle, Colorado: Colorado Geological Survey Resources Series RS-27, 40 p., 10 pls. 
East, J.A., 2013, Coal fields of the conterminous United States-National Coal Resource Assessment updated version: U.S. Geological Survey Open-File Report 2012-1205, 1 sheet, scale 1:5,000,000, accessed August 29, 2017, at http://pubs.usgs.gov/of/2012/1205.

Ehlen, J., 1967, Geology of state parks near Cape Arago, Coos County, Oregon: Ore Bin, v. 29, no. 4, p. 61-82. [Also available at http://ibrary.state.or.us/repository/2011/201112201509422/OBv29n04.pdf.]

Ellis, M.S., Gunther, G.L., Ochs, A.M., Cavaroc, V.V., Schuenemeyer, J.H., Power, H.C., Stricker, G.D, and Blake, D., 1999a, Coal resources of the Hanna and Carbon Basins, chap. HN of Resource assessment of selected Tertiary coal beds and zones in the northern Rocky Mountains and Great Plains region: U.S. Geological Survey Professional Paper 1625-A, 49 p., accessed August 29, 2017, at https://pubs.usgs.gov/pp/p1625a.

Ellis, M.S., Gunther, G.L., Ochs, A.M., Keighin, C.W., Goven, G.E., Schuenemeyer, J.H., Power, H.C., Stricker, G.D., and Blake, Dorsey, 1999b, Coal resources, Williston Basin, chap. WN of Fort Union Coal Assessment Team, Resource assessment of selected Tertiary coal beds and zones in the northern Rocky Mountains and Great Plains region: U.S. Geological Survey Professional Paper 1625-A, 74 p., accessed August 29, 2017, at https://pubs.usgs.gov/pp/p1625a.

Evans, G.W., 1912, The coal fields of King County: Olympia, Wash., E.L. Boardman [printer], Washington Geological Survey Bulletin 3, 247 p. [includes unnumbered pls.].

Evans, T.J., 1974, Bituminous Coal in Texas: Austin, University of Texas at Austin, Bureau of Economic Geology Handbook 4, $65 \mathrm{p}$.

Ferguson, J.A., 1906, Tenth Report of the Bureau of Agriculture, Labor and Industry of the State of Montana: Helena, Independent Publishing Company, 478 p.

Finley, R., 2011, Sequestration and Enhanced Coal Bed Methane-Tanquary Farms Test Site, Wabash County, Illinois-Final Report: Champaign, Illinois, University of Illinois at Urbana-Champaign, Midwest Geological Sequestration Consortium, 202 p., http://sequestration.org/resources/publish/TanquaryReportFinal.pdf.

Finn, T.M., Kirschbaum, M.A., Roberts, S.B., Condon, S.M., Roberts, L.N.R., and Johnson, R.C., 2009, Cretaceous-Tertiary composite total petroleum system (503402), Bighorn Basin, Wyoming and Montana, chap. 3 of U.S. Geological Survey Bighorn Basin Province Assessment Team, Petroleum systems and geologic assessment of oil and gas in the Bighorn Basin Province, Wyoming and Montana: U.S. Geological Survey Digital Data Series DDS-69-V, 163 p., accessed August 29, 2017, at https://pubs.usgs.gov/dds/dds-069/dds-069-v.

Flores, R.M., Cavaroc, V.V., Jr., and Bader, L.R., 1999a, Framework geology of Ferris and Hanna coal in the Hanna and Carbon Basins, chap. HF of Central Region Energy Resources Team, Resource assessment of selected Tertiary coal beds and zones in the northern Rocky Mountains and Great Plains region: U.S. Geological Survey Professional Paper 1625-A, p. HF1-HF17, accessed August 29, 2017, at https://pubs.usgs.gov/pp/p1625a.

Flores, R.M., and Keighin, C.W., 1999, A summary of Tertiary coal resources of the Wind River Basin, Wyoming, chap. SW of Central Region Energy Resources Team, Resource assessment of selected Tertiary coal beds and zones in the northern Rocky Mountains and Great Plains region: U.S. Geological Survey Professional Paper 1625-A, p. SW1-SW18, accessed August 29, 2017, at https://pubs.usgs.gov/pp/p1625a.

Flores, R.M., Keighin, C.W., and Nichols, D.J., 1992, Sedimentology, conglomerate petrology, and palynostratigraphy of the Fort Union Formation (Paleocene), Castle Gardens, Wind River Basin, Wyoming, in Sundell, K.A., and Anderson, T.C., eds., Road log volume for Rediscover the Rockies-AAPG-SEPM-EMD Rocky Mountain Section meeting, Casper, Wyoming, September 12-19, 1992: Casper, Wyo., Wyoming Geological Association, 43rd Field Conference, p. 21-27.

Gilliland, E.S., Ripepi, N., Conrad, M., Miller, M.J., and Karmis, M., 2013, Selection of monitoring techniques for a carbon storage and enhanced coalbed methane recovery pilot test in the Central Appalachian Basin: International Journal of Coal Geology, v. 118, p. 105-112, accessed August 29, 2017, at https://doi.org/10.1016/j.coal.2013.07.007.

Gunther, G.L., Like, K.K., Affolter, R.H., Hatch, J.R., Connolly, C.L., Treworgy, C.G., Andrews, W.A., and Weisenfluh, G.A., 2002, ArcView project for the assessment of the Springfield, Herrin, Danville, and Baker coals in the Illinois Basin, in Hatch, J.R., and Affolter, R.H., eds., Resource assessment of the Springfield, Herrin, Danville, and Baker coals in the Illinois Basin: U.S. Geological Survey Professional Paper 1625-D [CD-ROM]. 
Hatch, J.R., and Affolter, R.H., 2002, Geologic overview, chap. C of Hatch, J.R., and Affolter, R.H., eds., Resource assessment of the Springfield, Herrin, Danville, and Baker coals in the Illinois Basin: U.S. Geological Survey Professional Paper 1625-D [CD-ROM, also available at https://pubs.usgs.gov/pp/p1625d.]

Hatch, J.R., and Pawlewicz, M.J., 2007, Petroleum assessment of the Pottsville coal total petroleum system, Black Warrior Basin, Alabama and Mississippi, chap. 4 of Hatch, J.R., and Pawlewicz, M.J., eds., Geologic assessment of undiscovered oil and gas resources of the Black Warrior Basin Province, Alabama and Mississippi: U.S. Geological Survey Digital Data Series 69-I [CD-ROM, also available at https://pubs.usgs.gov/dds/dds-069/dds-069-i.]

Hewitt, J., 1984, Geologic overview, coal, and coalbed methane resources of the Black Warrior Basin-Alabama and Mississippi, in Rightmire, C.T., Eddy, G.E., and Kirr, J.N., eds., Coalbed methane resources of the United States: American Association of Petroleum Geologists, Studies in Geology Series 17, p. 73-104, accessed August 29, 2017, at http://archives.datapages.com/data/specpubs/basinar1/data/a138/a138/0001/0050/0073.htm.

Hettinger, R.D., 2009, A summary of coal distribution and geology in the Kaiparowits Plateau, Utah, chap. J of Kirschbaum, M.A., Roberts, L.N.R., and Biewick, L.R.H., eds., Geologic assessment of coal in the Colorado Plateau-Arizona, Colorado, New Mexico, and Utah: U.S. Geological Survey Professional Paper 1625-B [CD-ROM, also available at https://pubs.usgs.gov/pp/p1625b/Reports/Chapters/Chapter_J.pdf.]

Hogle, D.G., and Jones, R.W., 1991, Subsurface geology of Upper Cretaceous and Lower Tertiary coal-bearing rocks, Wind River Basin, Wyoming: [The Rocky Mountain Association of Geologists,] Mountain Geologist, v. 28, nos. 2-3, p. 13-35, accessed August 29, 2017, at http://archives.datapages.com/data/rmag/mg/1991/hogle.pdf.

Houseknecht, D.W., and Iannacchione, A.T., 1982, Anticipating facies-related coal mining problems in Hartshorne Formation, Arkoma Basin: American Association of Petroleum Geologists Bulletin, v. 66, no. 7, p. 923-946.

Iannacchione, A.T., and Puglio, D.G., 1979, Methane content and geology of the Hartshorne coalbed in Haskell and Le Flore Counties, Okla.: U.S. Bureau of Mines Report of Investigations 8407, 14 p., [Also available at https://www.cdc.gov/NIOSH/ Mining/UserFiles/works/pdfs/ri8407.pdf.]

Iannacchione, A.T., Kertis, C.A., Houseknecht, D.W., and Perr, J.H., 1983, Problems facing coal mining and gas production in the Hartshorne coalbeds of the western Arkoma Basin, OK: U.S. Bureau of Mines Report of Investigations 8795, 25 p., [Also available at https://www.cdc.gov/niosh/mining/UserFiles/works/pdfs/ri8795.pdf.]

IHS Inc., 2010, PIDM [Petroleum Information Data Model] relational U.S. well data [includes data current as of December 23, 2009]: Englewood, Colo., IHS Inc., database.

Intergovernmental Panel on Climate Change, 2005, IPCC Special Report on Carbon Dioxide Capture and Storage, prepared by Working Group III of the Intergovernmental Panel on Climate Change, Metz, B., Davidson, O., de Coninck, H., Loos, M., and Meyer, L., eds.: New York, Cambridge University Press for the Intergovernmental Panel on Climate Change, 442 p.

Johnson, R.C., and Finn, T.M., 2001, Potential for a basin-centered gas accumulation in the Raton Basin, Colorado and New Mexico: U.S. Geological Survey Bulletin 2184-B, 14 p. [Also available at https://pubs.usgs.gov/bul/b2184-b.]

Johnson, R.C., and Flores, R.M., 1993, Stratigraphy, areal distribution, and paleodepositional environments of Fort Union Formation coal beds, Wind River Reservation, Wyoming, implications for coalbed methane development, in Keefer, W.E., Metzger, W.J., and Godwin, L.H., eds., Wyoming Geological Association Special Symposium on oil and gas and other resources of the Wind River Basin, Wyoming; Casper, Wyoming, August 14-17, 1993: Cheyenne, Wyo., Bureau of Indian Affairs, Wyoming Geological Association Special Symposium, August 14-17, 1993, p. 281-294.

Jones, D.C., Schultz, J.E., and Murray, D.K., 1978, Coal resources and development map of Colorado: Colorado Geological Survey Map Series 9, scale 1:500,000.

Jones, K.B., Barnhart, L.E., Warwick, P.D., and Corum, M.D., 2019, Geospatial data for a preliminary GIS representation of deep coal areas for carbon dioxide storage in the contiguous United States and Alaska: U.S. Geological Survey data release, https://doi.org/10.5066/P90GDHSZ.

Jones, K.B., and Blondes, M.S., 2015, Carbon dioxide storage in unconventional reservoirs workshop-Summary of recommendations: U.S. Geological Survey Open-File Report 2015-1079, 10 p., accessed August 29, 2017, at http://dx.doi.org/10.3133/ofr20151079. 
Kinney, S.A., Scott, D.C., Osmonson, L.M., and Luppens, J.A., 2015, Geospatial data for coal beds in the Powder River Basin, Wyoming and Montana: U.S. Geological Survey Data Series 912, 7 p., accessed August 29, 2017, at https://pubs.er.usgs.gov/ publication/ds912.

Kirschbaum, M.A., ed., Roberts, L.N.R., and Biewick, L.R.H., 2000, Geologic assessment of coal in the Colorado PlateauArizona, Colorado, New Mexico, and Utah: U.S. Geological Survey Professional Paper 1625-B [Two CD-ROMs, also available at https://pubs.usgs.gov/pp/p1625b.]

Luppens, J.A., and Scott, D.C., 2015, Coal geology and assessment of coal resources and reserves in the Powder River Basin, Wyoming and Montana: U.S. Geological Survey Professional Paper 1809, 218 p. [Also available at https://doi.org/10.3133/ pp1809.]

Mapel, W.J., 1967, Bituminous coal resources of Texas: U.S. Geological Survey Bulletin 1242-D, p. D1-D28, accessed August 29, 2017, at https://pubs.usgs.gov/bul/1242d/report.pdf.

Martin, G.C., 1907, The Alaska coal fields: U.S. Geological Survey Bulletin 314-B, p. 40-46, accessed August 29, 2017, at https://pubs.er.usgs.gov/publication/b314B.

McIntyre, M.R., and Pashin, J.C., 2007, Carbon sequestration and enhanced coalbed methane recovery potential of the Cahaba and Coosa coalfields in the southern Appalachian thrust belt in 2007 International Coalbed Methane SymposiumMay 23-24, 2007, Tuscaloosa, Alabama, USA, the University of Alabama, College of Continuing Studies [proceedings]: Tuscaloosa, Ala., International Coalbed Methane Symposium, paper 0708, [Also available at http://www2.ogb.state.al.us/ CO2/SECARB2/secarb2_files/0708.pdf.]

McVay, D.A., Ayers, W.B., Jr., Jensen, J.L., Garduno, J.L., Hernandez, G.A., Bello, R.O., and Ramazanova, R.I., 2007, $\mathrm{CO}_{2}$ sequestration potential of Texas low-rank coals: College Station, Tex., Texas Engineering Experiment Station, Final Technical Report DE-FC26-02NT41588, 127 p.

Merritt, R.D., and Hawley, C.C., 1986, Map of Alaska's coal resources: Alaska Division of Geological and Geophysical Surveys Special Report 37, scale 1:2,500,000.

Montgomery, S.L., Barker C.E., Seamount, D., Dallegge, T.A., and Swenson, R.F., 2003, Coalbed methane, Cook Inlet, southcentral Alaska-A potential giant gas resource: American Association of Petroleum Geologists Bulletin, v. 87, no. 1, p. 1-13.

Murphy, E.C., 2006, The lignite reserves of North Dakota: North Dakota Geological Survey Report of Investigations 104, 141 p.

National Energy Technology Laboratory (NETL), 2010a, 2010 Carbon Sequestration Atlas of the United States and Canada (3d ed.): Washington, D.C., U.S. Department of Energy. [Also available at https://www.netl.doe.gov/KMD/CDs/ atlasIII/2010atlasIII.pdf.]

National Energy Technology Laboratory, 2010b, Midwest Geological Sequestration Consortium - Validation Phase: National Energy Technology Laboratory fact sheet, 8 p.

National Energy Technology Laboratory, 2012, Southeast Regional Carbon Sequestration Partnership—validation phase: National Energy Technology Laboratory Fact Sheet NT42590-P2, 8 p., accessed August 29, 2017, at https://www.netl.doe.gov/publications/factsheets/project/NT42590-P2.pdf.

Nations, J.D., Swift, R.L., and Haven, H.W. Jr., 2000, Summary of Cretaceous stratigraphy and coal distribution, Black Mesa Basin, Arizona, chap. H of Kirschbaum, M.A., Roberts, L.N.R., and Biewick, L.R.H., eds., Geologic assessment of coal in the Colorado Plateau - Arizona, Colorado, New Mexico, and Utah: U.S. Geological Survey Professional Paper 1625-B [CD-ROM, also available at https://pubs.usgs.gov/pp/pp1625b.]

Northern and Central Appalachian Basin Coal Regions Assessment Team, 2001, 2000 resource assessment of selected coal beds and zones in the northern and central Appalachian basin coal regions: U.S. Geological Survey Professional Paper 1625-C, accessed August 29, 2017, at https://pubs.usgs.gov/pp/p1625c.]

Pashin, J.C., Clark, P.E., McIntyre-Redden, M.R., Carroll, RE., Esposito, R.A., Oudinot, A.Y., and Koperna, G.J., Jr., 2015, SECARB $\mathrm{CO}_{2}$ injection test in mature coalbed methane reservoirs of the Black Warrior Basin, Blue Creek Field, Alabama: International Journal of Coal Geology, v. 144-145, p. 71-87, accessed August 29, 2017, at http://dx.doi.org/10.1016/j.coal.2015.04.003. 
Pashin, J.C., McIntyre, M.R., Carroll, R.E., Groshong, R.H., Jr., and Bustin, R.M., 2009, Carbon sequestration and enhanced recovery potential of mature coalbed methane reservoirs in the Black Warrior Basin, in Grobe, M., Pashin, J.C., and Dodge, R.L., eds., Carbon dioxide sequestration in geological media - State of the science: American Association of Petroleum Geologists Studies in Geology 59, p. 125-147, accessed June 26, 2018, at http://archives.datapages.com/data/specpubs/ study59/CHAPTER08/CHAPTER08.HTM.

Pashin, J.C., and Raymond, D.E., 2004, Glacial-eustatic control of coalbed methane reservoir distribution (Pottsville Formation; Lower Pennsylvanian) in the Black Warrior Basin of Alabama in 2004 International Coalbed Methane Symposium, proceedings-May 3-7, 2004, Bryant Conference Centre, The University of Alabama, Tuscaloosa, Alabama: Tuscaloosa, Ala., International Coalbed Methane Symposium, paper 0413.

Pashin, J.C., Ward, W.E. II, Winston, R.B., Chandler, R.V., Bolin, D.E., Richter, K.E., Osborne, W.E., and Sarnecki, J.C., 1991, Regional analysis of the Black Creek-Cobb coal-bed-methane target interval, Black Warrior basin, Alabama: Geological Survey of Alabama Bulletin 145, 127 p.

Philips, W.M., and Walsh, T.J., 1981, Coal Geology of King County, Washington: Washington Geologic Newsletter, v. 9, no. 2, p. 1-11. [Also available at http://www.dnr.wa.gov/Publications/ger_washington_geology_1981_v9_no2.pdf.]

Pierce, B.S., and Dennen, K.O., eds., 2009, The National Coal Resource Assessment overview: U.S. Geological Survey Professional Paper 1625-F, 402 p., accessed August 29, 2017, at https://pubs.usgs.gov/pp/1625f.

Rice, D.D., Finn, T.M., and Hatch, J.R., 1995, Forest City Basin Province (056), in Gautier, D.L., Dolton, G.L., Takahashi, K.I., and Varnes, K.L., eds., 1995 national assessment of United States oil and gas resources-Results, methodology, and supporting data: U.S. Geological Survey Digital Data Series 30, Release 2, [CD-ROM, also available at https://pubs.usgs.gov/ dds/dds-030/DDS-30.html.]

Roberts, S. B., and Rossi, G.S., 1999, A Summary of Coal in the Fort Union Formation (Tertiary: Paleocene), Bighorn Basin, Wyoming and Montana, Chapter SB, in Fort Union Coal Assessment Team, 1999 Resource assessment of selected Tertiary coal beds and zones in the Northern Rocky Mountains and Great Plains Region: U.S. Geological Survey Professional Paper 1625-A, 33 p. [CD-ROM, also available at https:/pubs.usgs.gov/pp/p1625a/pp1625A.html.]

Ryder, R.T., Crangle, R.D., Jr., Trippi, M.H., Swezey, C.S., Lentz, E.E., Rowan, E.L., and Hope, R.S., 2009, Geologic cross section D-D' through the Appalachian basin from the Findlay arch, Sandusky County, Ohio, to the Valley and Ridge province, Hardy County, West Virginia: U.S. Geological Survey Scientific Investigations Map 3067, 2 sheets, 52-p. pamphlet. [Also available at https://pubs.usgs.gov/sim/3067.]

Ryder, R.T., Swezey, C.S., Crangle, R.D., Jr., and Trippi, M.H., 2008, Geologic cross section E-E' through the Appalachian basin from the Findlay arch, Wood County, Ohio, to the Valley and Ridge province, Pendleton County, West Virginia: U.S. Geological Survey Scientific Investigations Map 2985, 2 sheets, 48-p. pamphlet. [Also available at https://pubs.usgs.gov/ $\operatorname{sim} / 2985$.]

Ryder, R.T., Trippi, M.H., and Swezey, C.S., 2015, Geologic cross section I-I' through the Appalachian basin from the eastern margin of the Illinois basin, Jefferson County, Kentucky, to the Valley and Ridge Province, Scott County, Virginia: U.S. Geological Survey Scientific Investigations Map 3343, 2 sheets, 41-p. pamphlet. [Also available at https://doi.org/10.3133.sim3343.]

Ryder, R.T., Trippi, M.H., Swezey, C.S., Crangle, R.D., Jr., Hope, R.S., Rowan, E.L., and Lentz, E.E., 2012, Geologic cross section $\mathrm{C}-\mathrm{C}^{\prime}$ through the Appalachian basin from Erie County, north-central Ohio, to the Valley and Ridge province, Bedford County, south-central Pennsylvania: U.S. Geological Survey Scientific Investigations Map 3172, 2 sheets, 70-p. pamphlet. [Also available at https://pubs.usgs.gov/sim/3172.]

Ryer, T.A., 1981, Deltaic coals of Ferron Sandstone Member of Mancos Shale—Predictive model for Cretaceous coal-bearing strata of Western Interior: American Association of Petroleum Geologists Bulletin, v. 65, no. 11, p. 2323-2340. [Also available at https://doi.org/10.1306/03b59990-16d1-11d7-8645000102c1865d.]

Sable, E.G., and Stricker, G.D., 1987, Coal in the National Petroleum Reserve in Alaska (NPRA)—Framework geology and resources, in Tailleur, I.L., and Weimer, P., eds., Alaskan North Slope geology: Bakersfield, Calif., Pacific Section, Society of Economic Paleontologists and Mineralogists Special Publication 50, p. 195-215. [Also available at http://archives.datapages.com/data/pac_sepm/066/066001/pdfs/195.htm.] 
Scott, D.C., Haacke, J.E., Osmonson, L.M., Luppens, J.A., Pierce, P.E., and Rohrbacher, T.J., 2011, Assessment of coal geology, resources, and reserves in the northern Wyoming Powder River Basin: U.S. Geological Survey Open-File Report 2010-1294, 136 p., accessed August 29, 2017, at https://pubs.usgs.gov/of/2010/1294.

Shomaker, J.W., and Whyte, M.R., 1977, Geologic appraisal of deep coals, San Juan Basin, New Mexico: New Mexico Bureau of Mines \& Mineral Resources Circular 155, 39 p., 6 tables, 13 figs.

Sidle, W.C., 1981, Potential hydrologic effects of developing coal and other geoenergy resources in Oregon-A review: U.S. Geological Survey Open-File Report 81-1014, 34 p. [Also available at https://pubs.er.usgs.gov/publication/ofr811014.]

Stark, J.R., and McDonald, M.G., 1980, Ground water of coal deposits, Bay County, Michigan: U.S. Geological Survey OpenFile Report 80-591, 42 p., accessed August 29, 2017, at https://pubs.er.usgs.gov/publication/ofr80591.

Stevens, S., 2009, Centralia (Washington State) Geologic Formation $\mathrm{CO}_{2}$ Storage Assessment: WESTCARB Phase II: Advanced Resources International, U.S. Department of Energy Contract No. DE-FC26-05NT42593.

Stevens, S.H., Lombardi, T.E., Kelso, B.S., and Coates, J.M., 1992, A geologic assessment of natural gas from coal seams in the Raton and Vermejo Formations, Raton Basin: GRI [Gas Research Institute] Topical Report 92/0345, 84 p.

Stricker, G.D., 1999, Bull Mountain Basin, Montana, chap. SM of Resource assessment of selected Tertiary coal beds and zones in the northern Rocky Mountains and Great Plains region: U.S. Geological Survey Professional Paper 1625-A, p. SM-1-SM-10, accessed August 29, 2017, at https://pubs.usgs.gov/pp/p1625a.

Swezey, C.S., Hatch, J.R., East, J.A., Hayba, D.O., and Repetski, J.E., 2015, Total petroleum systems of the Michigan BasinPetroleum geology and geochemistry and assessment of undiscovered resources, chap. 2 of U.S. Geological Survey Michigan Basin Province Assessment Team, Geologic assessment of undiscovered oil and gas resources of the U.S. portion of the Michigan Basin: U.S. Geological Survey Data Series 69-T, 162 p., accessed August 29, 2017, at http:/pubs.usgs.gov/dds/ dds-069/dds-069-t.

Tabet, D.E., 2000, Coal resources of the Henry Mountains coal field, Utah, chap. R of Kirschbaum, M.A., Roberts, L.N.R., and Biewick, L.R.H., eds., Geologic assessment of coal in the Colorado Plateau-Arizona, Colorado, New Mexico, and Utah: U.S. Geological Survey Professional Paper 1625-B [CD-ROM, also available at https://pubs.usgs.gov/pp/p1625b.]

Tewalt, S.J., Kinney, S.A., Merrill, M.D., 2008, GIS representation of coal-bearing areas in North, Central, and South America: U.S. Geological Survey Open-File Report 2008-1257, accessed August 29, 2017, at http://pubs.usgs.gov/of/2008/1257.

Tremain, C.M., Hornbaker, A.L., Holt, R.D., Murray, D.K., and Ladwig, L.R., 1996, 1995 summary of coal resources in Colorado: Colorado Geological Survey Special Publication 41, 19 p., 11 figs., 6 tables. [Also available at http://geosurvey.state.co.us/pubs/online/Documents/1996\%20SP-41.pdf.]

Treworgy, J.D. and Whitaker, S.T., 1990a, 1 o'clock cross section in the Illinois Basin, Wayne County, Illinois, to Lake County, Indiana: Illinois State Geological Survey Open-File Series 1990-5. [Also available at http://library.isgs.uiuc.edu/Pubs/pdfs/ ofs/1990/ofs1990-05.pdf.]

Treworgy, J.D. and Whitaker, S.T., 1990b, 3 o'clock cross section in the Illinois Basin, Wayne County, Illinois, to Switzerland County, Indiana: Illinois State Geological Survey Open-File Series 1990-3. [Also available at http://library.isgs.uiuc.edu/ Pubs/pdfs/ofs/1990/ofs1990-03.pdf.]

Treworgy, J.D., Whitaker, S.T., and Sargent, M.L., 1992, Southwest-northeast cross section in the Illinois Basin, southeastern flank of the Ozark Dome, Missouri, to southern Illinois: Illinois State Geological Survey Open-File Series 1992-2. [Also available at http://library.isgs.uiuc.edu/Pubs/pdfs/ofs/1992/ofs1992-02.pdf.]

University of North Dakota Energy \& Environmental Research Center, 2014, $\mathrm{CO}_{2}$ sequestration test in a deep, unminable lignite seam: University of North Dakota Energy \& Environmental Research Center Fact Sheet No. 10B, accessed August 29, 2017, at http://www.undeerc.org/PCOR/newsandpubs/pdf/FS10-Lignite-CO2-Sequestration-Test-Unminable-Coal-Seam-North-Dakota.pdf.

U.S. Environmental Protection Agency [EPA], 2004a, The San Juan Basin, attachment 1 of U.S. Environmental Protection Agency, Evaluation of impacts to the underground sources of drinking water by hydraulic fracturing of coalbed methane reservoirs: U.S. Environmental Protection Agency Publication 816-R-04-003, p. A1-1-A1-8, accessed July 3, 2018, at https://nepis.epa.gov/Exe/ZyPURL.cgi?Dockey=P100A99N.TXT. 
U.S. Environmental Protection Agency [EPA], 2004b, The Western Interior Coal Region, attachment 8 of U.S. Environmental Protection Agency, Evaluation of impacts to the underground sources of drinking water by hydraulic fracturing of coalbed methane reservoirs: U.S. Environmental Protection Agency Publication 816-R-04-003, p. A8-1-A8-11, accessed July 3, 2018, at https://nepis.epa.gov/Exe/ZyPURL.cgi?Dockey=P100A99N.TXT.

U.S. Environmental Protection Agency [EPA], 2004c, The Raton Basin, attachment 9 of U.S. Environmental Protection Agency, Evaluation of impacts to the underground sources of drinking water by hydraulic fracturing of coalbed methane reservoirs: U.S. Environmental Protection Agency Publication 816-R-04-003, p. A9-1-A9-5, accessed July 3, 2018, at https://nepis.epa.gov/Exe/ZyPURL.cgi?Dockey=P100A99N.TXT.

U.S. Environmental Protection Agency [EPA], 2004d, The Sand Wash Basin, attachment 10 of U.S. Environmental Protection Agency, Evaluation of impacts to the underground sources of drinking water by hydraulic fracturing of coalbed methane reservoirs: U.S. Environmental Protection Agency Publication 816-R-04-003, p. A10-1-A10-5, accessed July 3, 2018, at https://nepis.epa.gov/Exe/ZyPURL.cgi?Dockey=P100A99N.TXT.

U.S. Environmental Protection Agency [EPA], 2004e, The Washington Coal Region (Pacific and central), attachment 11 of U.S. Environmental Protection Agency, Evaluation of impacts to the underground sources of drinking water by hydraulic fracturing of coalbed methane reservoirs: U.S. Environmental Protection Agency Publication 816-R-04-003, p. A11-1-A11-7, accessed July 3, 2018, at https://nepis.epa.gov/Exe/ZyPURL.cgi?Dockey=P100A99N.TXT.

U.S. Environmental Protection Agency [EPA], 2009, Safe Drinking Water Act (SDWA): U.S. Environmental Protection Agency website, accessed October 15, 2012, at http://www.epa.gov/ogwdw/sdwa/index.html.

U.S. Environmental Protection Agency [EPA], 2010, Final rule for Federal requirements under the underground injection control (UIC) program for carbon dioxide $\left(\mathrm{CO}_{2}\right)$ geologic sequestration (GS) wells: U.S. Environmental Protection Agency website, accessed October 15, 2012, at http://water.epa.gov/type/groundwater/uic/class6/gsregulations.cfm.

U.S. Geological Survey, 2012, U.S. Geological Survey National Coal Resources Data System UStratigraphic (USTRAT) database: U.S. Geological Survey website, accessed August 29, 2017, at http://energy.usgs.gov/Tools/ NationalCoalResourcesDataSystem.aspx.

U.S. Geological Survey Carbon Dioxide Storage Resources Assessment Team, 2013, National assessment of geologic carbon dioxide storage resources-Summary: U.S. Geological Survey Fact Sheet 2013-3020, 6 p., accessed August 29, 2017, at https://pubs.usgs.gov/fs/2013/3020.

U.S. Geological Survey Colorado Plateau Coal Assessment Team, 2000, Geologic assessment of coal in the Colorado PlateauArizona, Colorado, New Mexico, and Utah: U.S. Geological Survey Professional Paper 1625-B, Version 1.0, Appendix, [CD-ROM, also available at https://pubs.usgs.gov/pp/p1625b.]

U.S. Geological Survey Fort Union Assessment Team, 1999, 1999 Resource assessment of selected Tertiary coal beds and zones in the Northern Rocky Mountains and Great Plains region: U.S. Geological Survey Professional Paper 1625-A, Version 1.2, Discs 1 and 2, [CD-ROM, also available at https://pubs.usgs.gov/pp/p1625a.]

Vaninetti, G.E., 1979, Coal Stratigraphy of the John Henry Member of the Straight Cliffs Formation, Kaiparowits Plateau, Utah: Salt Lake City, University of Utah, M.S. thesis, 272 p., accessed August 29, 2017, at http://content.lib.utah.edu/utils/getfile/ collection/etd2/id/754/filename/246.pdf.

Wahrhaftig, C., Bartsch-Winkler, S., and Stricker, G.D., 1994, Coal in Alaska, in Plafker, G., and Berg, H.C., eds., The geology of Alaska: Geological Society of America, The geology of North America, v. G-1, p. 937-978.

Walsh, T.J., and Phillips, W.M., 1983, Rank of Eocene coals in western and central Washington state-A reflection of Cascade plutonism?: Washington Division of Geology and Earth Resources Open-File Report 83-16, 21 p., accessed August 29, 2017, at http://www.dnr.wa.gov/publications/ger_ofr83-16_eocene_coal_rank.pdf.

Wanless, H.R., and Shideler, G.L., 1975, Michigan Basin region, chap. D of McKee, E.D., and Crosby, E.J., coords., Paleotectonic investigations of the Pennsylvanian System in the United States, Part I, Introduction and regional analyses of the Pennsylvanian System: U.S. Geological Survey Professional Paper 853-1, p. 63-70, accessed August 29, 2017, at https://pubs.er.usgs.gov/publication/pp08531.

Ward, W.E., II, 1984, Reserve base of bituminous coal and lignite in Alabama: Geological Survey of Alabama Circular 118, 102 p. 
Warwick, P.D., Charpentier, R.R., Cook, T.A., Klett, T.R., Pollastro, R.M., and Schenk, C.J., 2007, Assessment of undiscovered oil and gas resources in Cretaceous-Tertiary coal beds of the Gulf Coast region, 2007: U.S. Geological Survey Fact Sheet 2007-3039, 2 p., accessed August 29, 2017, at https://pubs.usgs.gov/fs/2007/3039.

Washburne, C.W., 1910, Contributions to economic geology, 1908, part II, mineral fuels-South Park coal field, Colorado: U.S. Geological Survey Bulletin 381, p 307-316, accessed August 29, 2017, at https://pubs.er.usgs.gov/publication/b381.

Wayland, R.G., 1965, The correlation of coal beds in Squaw Basin and part of Eden Ridge, T. 33 S., R. 11 W., W. M., southwestern Oregon: U.S. Geological Survey Open-File Report 65-171, 34 p. [Also available at https://pubs.er.usgs.gov/ publication/ofr65171.]

Whitaker, S.T., and Treworgy, J.D., 1990, 9 o'clock cross section in the Illinois Basin, Wayne County, Illinois, to St. Clair County, Illinois: Illinois State Geological Survey Open-File Series 1990-4. [Also available at http://library.isgs.uiuc.edu/Pubs/ pdfs/ofs/1990/ofs1990-04.pdf.]

Whitaker, S.T., Treworgy, J.D., and Noger, M.C., 1992a, 6 o'clock cross section in the Illinois Basin, Wayne County, Illinois, to Gibson County, Tennessee: Illinois State Geological Survey Open-File Series 1992-10. [Also available at http://library.isgs.uiuc.edu/Pubs/pdfs/ofs/1992/ofs1992-10.pdf.]

Whitaker, S.T., Treworgy, J.D., Sargent, M.L., and Noger, M.C., 1992b, Northwest-southeast cross section in the Illinois Basin, Sparta Shelf, southern Illinois, to Rough Creek Graben, western Kentucky: Illinois State Geological Survey Open-File Series 1992-3. [Also available at http://library.isgs.uiuc.edu/Pubs/pdfs/ofs/1992/ofs1992-03.pdf.]

Wickstrom, L.H., Venteris, E.R., Harper, J.A., McDonald, J., Slucher, E.R., Carter, K.M., Greb, S.F., Wells, J.G., Harrison, W.B., III, Nuttall, B.C., Riley, R.A., Drahovzal, J.A., Rupp, J.A., Avary, K.L., Lanham, S., Barnes, D.A., Gupta, N., Baranoski, M.A., Radhakkrishnan, P., Solis, M.P., Baum, G.R., Powers, D., Hohn, M.E., Parris, M.P., McCoy, K., Grammer, G.M., Pool, S., Luckhardt, C., and Kish, P., 2005, Characterization of geologic sequestration opportunities in the MRCSP regionPhase I task report: Ohio Division of Natural Resources Open-File Report 2005-1, 151 p., accessed August 29, 2017, at http://geosurvey.ohiodnr.gov/portals/geosurvey/PDFs/OpenFileReports/OFR_2005-1.pdf.

Woodruff, E.G., 1914, The Glacier coal field, Whatcom County, Washington, in Woodruff, E.G., and Lesher, C.E., Coal fields in Idaho, Washington, and Oregon: U.S. Geological Survey Bulletin 541, p. 389-398, accessed August 29, 2017, at https://pubs.er.usgs.gov/publication/b541.

Woolsey, L.H., Richards, R.W., and Lupton, C.T., 1917, The Bull Mountain coal field, Musselshell and Yellowstone Counties, Montana: U.S. Geological Survey Bulletin 647, 218 p., 1 sheet, scale 1:125,000, accessed August 29, 2017, at https://pubs.er.usgs.gov/publication/b647. 



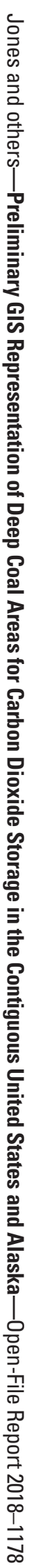

